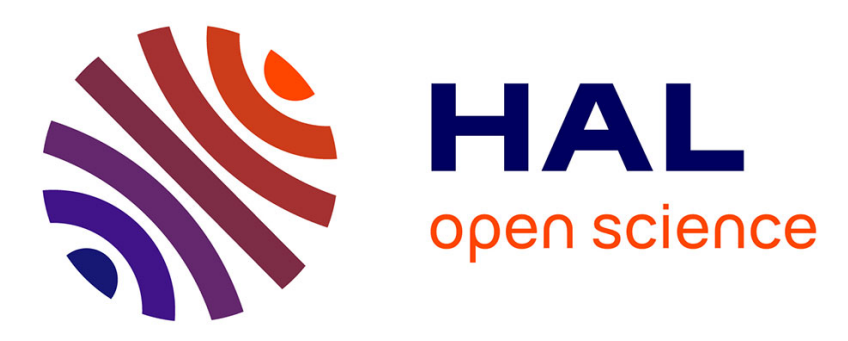

\title{
Hydrolytic cleavage of N6-substituted adenine derivatives by eukaryotic adenine and adenosine deaminases
}

Hana Pospíšilová, Marek Šebela, Ondřej Novák, Ivo Frébort

\section{- To cite this version:}

Hana Pospíšilová, Marek Šebela, Ondřej Novák, Ivo Frébort. Hydrolytic cleavage of N6-substituted adenine derivatives by eukaryotic adenine and adenosine deaminases. Bioscience Reports, 2008, 28 (6), pp.335-347. 10.1042/BSR20080081 . hal-00479304

\section{HAL Id: hal-00479304 https://hal.science/hal-00479304}

Submitted on 30 Apr 2010

HAL is a multi-disciplinary open access archive for the deposit and dissemination of scientific research documents, whether they are published or not. The documents may come from teaching and research institutions in France or abroad, or from public or private research centers.
L'archive ouverte pluridisciplinaire HAL, est destinée au dépôt et à la diffusion de documents scientifiques de niveau recherche, publiés ou non, émanant des établissements d'enseignement et de recherche français ou étrangers, des laboratoires publics ou privés. 
Hydrolytic cleavage of $N^{6}$-substituted adenine derivatives by eukaryotic adenine and adenosine deaminases

Hana POSPÍŠILOVÁ*, Marek ŠEBELA*, Ondřej NOVÁK ${ }^{\dagger}$ and Ivo FRÉBORT ${ }^{*}, 1$

*Department of Biochemistry, Faculty of Science, Palacký University and ${ }^{\dagger}$ Laboratory of Growth Regulators, Palacký University/Institute of Experimental Botany AS CR, Šlechtitelu 11, 78371 Olomouc, Czech Republic

Page heading title: Hydrolysis of adenine derivatives by adenine/adenosine deaminases

Abbreviations: ADE, adenine deaminase (EC 3.5.4.2); ADA, adenosine deaminase (EC 3.5.4.4)

${ }^{1}$ To whom correspondence should be addressed: Tel. +420-585634923; fax +420-585634936; e-mail address: ivo.frebort@upol.cz 


\section{Synopsis}

Homogeneous adenine deaminases (EC 3.5.4.2) from the yeast Saccharomyces cerevisiae and Schizosaccharomyces pombe and a putative adenosine deaminase (EC 3.5.4.4) from Arabidopsis thaliana were obtained for the first time as purified recombinant proteins by molecular cloning of the corresponding genes and their overexpression in Escherichia coli. The enzymes showed comparable molecular properties to well known mammalian adenosine deaminases, but exhibited much lower $k_{\text {cat }}$ values. Adenine was the most favored substrate for the yeast enzymes, whereas the plant enzyme showed only very low activities with either adenine, adenosine, AMP or ATP. Interestingly, the yeast enzymes also hydrolyzed $N^{6}$-substituted adenines from the group of plant hormones cytokinins, cleaving them to inosine and the corresponding side-chain amine. The hydrolytic cleavage of synthetic cytokinin 2,6-disubstituted analogues that are used in cancer therapy, such as olomoucine, roscovitine and bohemine, was subsequently found also for a reference sample of human adenosine deaminase (ADA1). ADA1, however, showed a different reaction mechanism than the yeast enzymes, hydrolyzing the compounds to an adenine derivative and a side chain alcohol. The reaction products were identified using reference compounds on HPLC coupled to UV and Q-TOF detectors.

The ADA1 activity may constitute the debenzylation metabolic route already described for bohemine and as a consequence, it may compromise physiological or therapeutic effect of exogenously applied cytokinin derivatives.

Keywords: adenine/adenosine deaminase, aminohydrolase, cytokinin, olomoucine, bohemine, roscovitine 


\section{INTRODUCTION}

Aminohydrolases adenine deaminase (ADE, EC 3.5.4.2; catalyzing irreversible deamination of adenine to hypoxanthine) and adenosine deaminase (ADA, EC 3.5.4.4; catalyzing irreversible deamination of adenosine to inosine) are enzymes that are responsible for the metabolic salvage of purines. Several subclasses of these enzymes have been already described and with the recent knowledge of full genome sequences of many organisms, it is possible to identify encoding genes and group the enzymes according to primary structure $[1,2]$. Fungal adenine deaminases share a relatively high sequence homology with both prokaryotic and eukaryotic adenosine deaminases that constitute a known family of $\alpha / \beta$ barrel enzymes [3]. Prokaryotic adenine deaminases form a specific group that differs structurally and evolutionary from the above.

Natural substrates of these enzymes are adenine and adenosine, respectively, but the enzymes can also hydrolyze 6-chloro-substituted derivatives. Adenosine deaminase can also convert other purine compounds like 2-amino-6-chloropurine riboside [4], 6-methoxypurine riboside [5], 6methylaminopurine ribonucleoside [6], as well as deoxyribose derivatives, AMP, ADP and ATP [7], and cAMP [8]. Metals ions in specific concentrations are in some cases essential for the activity [9, $10]$.

Proteins that exhibit adenosine deaminase activity include not only adenosine deaminase (EC 3.5.4.4), but also ADA regulatory proteins (only in prokaryotes) with different conserved structural domains (EC 2.1.1.63) and tRNA-specific adenosine deaminases (ADAT). ADAT was the first prokaryotic RNA editing enzyme to be identified in E. coli [11]. Another type of adenosine deaminase acting on RNA (ADAR) has the ability to deaminate adenosines in any long double-stranded RNA and convert them to inosines. These enzymes are commonly found in animals, but not known in other organisms [12].

Two different isoenzymes of adenosine deaminase are found in higher eukaryotes [13], ADA1 and ADA2 that are encoded by different genes [14]. In humans, almost all ADA activity is attributed to a single-chain Zn-binding protein ADA1, whereas ADA2 is found in negligible quantities in serum and may be produced by monocytes [15]. ADA1 is expressed in all human tissues, its activity levels being relatively high in thymus and duodenum (about $10 \mathrm{nkat} / \mathrm{mg}$ ), whereas more than 500 -fold lower in liver [16].

Adenine/adenosine deaminases are constitutive components of purine metabolism and their impairment may cause serious disorders [17]. In humans, adenosine deaminase deficiency links to severe combined immunodeficiency and as such it was approved for the first gene therapy trial [17]. Lack of ADA1 activity leads to an accumulation of dATP that causes inhibition of the ribonucleotide diphosphate reductase activity, which is the enzyme that synthesizes DNA and RNA required during lymphocyte proliferation. On the other hand, mutations leading to overexpression cause hemolytic anemia. There is also some evidence that mutations on the other allele (ADA2) may lead to autism [18].

The crystal structure of adenosine deaminase was solved for the enzymes from mouse [19] and cow [20]. The protein is folded as an eight-stranded parallel $\alpha / \beta$ barrel with a deep pocket at the $\beta$-barrel Cterminal end where the active site is formed from Glu and Asp residues and contains $\mathrm{Zn}^{2+}$ ion.

There are only scarce reports on the adenosine deaminase in plants. Although completed genome databases of Arabidopsis thaliana and other plants show the presence of putative encoding genes, the corresponding proteins have not been obtained so far nor the activity towards adenosine demonstrated. The physiological role of these enzymes in plants is unclear, since no activity was detected in plant extracts. Some articles even speculate that adenosine deaminase is not present at all in plant tissues [21-23] or that the enzyme activity is too low for efficient adenosine recycling that might be instead controlled by adenosine kinase (EC 2.7.1.77) [24].

In this paper, we describe cloning and functional expression of three adenine/adenosine deaminase genes, AAH1 from Saccharomyces cerevisiae (encoding the protein Aah1p), SPBC1198.02 from Schizosaccharomyces pombe and At4g04880 from Arabidopsis thaliana. The genes from yeasts have already been cloned and annotated to encode adenine deaminases of the same subfamily as the enzyme from Aspergillus nidulans that was obtained as a recombinant protein and characterized [3]. The gene from $A$. thaliana was identified by database search (annotated as adenosine/AMP deaminase family protein). All three enzymes were obtained as recombinant proteins, purified to homogeneity and 
showed to hydrolyze adenine compounds. Interestingly, the yeast enzymes also exhibited a low activity towards $N^{6}$-substituted adenines that are commonly known as plant hormones cytokinins. In plants, the hormones cytokinins act via specific plasma membrane receptors within a two-component signaling system and regulate numerous developmental and physiological processes, including apical dominance, flower and fruit development, leaf senescence, and seed germination [25]. They are often used as exogenous additives to control plant micropropagation. Some other cytokinin derivatives exhibit anticancer properties due to their ability to inhibit cyclin-dependent kinases [26] or find applications in skin protective cosmetics as they delay ageing of human fibroblasts [27] and protect against oxidative damage of DNA [28]. We found the activity towards some of these compounds for a reference sample of human adenosine deaminase (ADA1).

\section{MATERIALS AND METHODS}

\section{Chemicals, vectors, enzymes and biological material}

$N^{6}$-(2-isopentenyl)adenine 9-glucoside, trans-zeatin (6-((E)-4-hydroxy-3-methylbut-2enylamino)purine), trans-zeatin 9-riboside, trans-zeatin 9-glucoside, $m$-topolin (6-(3hydroxybenzyl)aminopurine), kinetin (6-furfurylaminopurine), olomoucine (6-benzylamino-2-(2hydroxyethylamino)-9-methylpurine), olomoucine II (6-(2-hydroxybenzylamino)-2(R)-[1(hydroxymethyl)propyl]amino-9-isopropylpurine), roscovitine (6-benzylamino-2-[1-(hydroxymethyl)propyl]amino-9-isopropylpurine), and bohemine (6-benzylamino-2-(3-hydroxypropylamino)9-isopropylpurine) were from OlChemIm (Olomouc, Czech Republic). $N^{6}$-methyl-isopentenyladenine that had been synthesized according to a published protocol [29] was donated by Kristin Bilyeu (USDA/University of Missouri, Columbia, MO, USA). Cyclin-dependent kinase inhibitors bohemine, roscovitine, olomoucine and olomoucine II were further purified by HPLC to remove trace impurities on a System Gold (Beckman, Fullerton, CA, USA) equipped with a Symmetry C18 column, $150 \mathrm{~mm}$ x $2.1 \mathrm{~mm}$ i.d., $5 \mu \mathrm{m}$ particles (Waters, Milford, MA, USA) in $15 \mathrm{mM}$ ammonium formate, $\mathrm{pH}$ 4.0, with a linear gradient of methanol from 10 to $90 \%$ in $25 \mathrm{~min}$ followed by a 5 -min isocratic elution, in a flow rate of $0.3 \mathrm{ml} / \mathrm{min}$ at $25{ }^{\circ} \mathrm{C}$.

6-Amino-2-(3-hydroxypropylamino)-9-isopropylpurine and 6-amino-2-[(1-hydroxymethyl) propyl]amino-9-isopropylpurine that had been synthesized according to a published protocol [30] were kindly provided by Libor Havlíček from the Institute of Experimental Botany, AS CR, Prague.

All other chemicals were from Sigma-Aldrich (Steinheim, Germany). PCR fragment isolation kits, plasmid purification kits and Ni-NTA agarose were from Qiagen (Hilden, Germany). Bio-Rad Protein Assay kit (Bio-Rad, Hercules, CA, USA) was used to assess protein concentration.

Advantage DNA polymerase used for the cloning to the pDrive vector (Qiagen) was from Clontech (Mountain View, CA, USA) and blunt-end generating proofreading polymerase Phusion ${ }^{\mathrm{TM}}$ used for cloning into pET100/D-TOPO and pET151/D-TOPO vectors (Invitrogen, Carlsbad, CA, USA) was obtained from Finnzymes (Espoo, Finland). Adenosine deaminase from human erythrocytes (ADA1) was a certified reference material BCR-647 purchased from Sigma-Aldrich (catalytic activity was 2.55 $\mu \mathrm{kat} / 1[31])$.

\section{Cloning of the yeast adenine deaminase genes}

The Saccharomyces cerevisiae strain used was 23344c (MAT $\alpha$ ura3), which is derived from the wild type strain S1278b [32]. Schizosaccharomyces pombe wild type $972 \mathrm{~h}$ - was kindly provided by Marie Kopecká (Department of Biology, Faculty of Medicine, Masaryk University in Brno, Czech Republic). Fractions of genomic DNA from $S$. pombe and $S$. cerevisiae were isolated according to an established protocol [33].

The gene sequence SPBC1198.02 from S. pombe (GeneID: 2540066, no introns) was amplified using Advantage DNA polymerase (annealing at $58^{\circ} \mathrm{C}, 30$ cycles) and oligonucleotide primers $5^{\prime}$ GGA GCG ATA TTG TGG GTG AT-3' (forward) and 5'-TTG ATT AAG CTT GAA CTT CCA CAG-3' (reverse), inserted into pDrive vector by U/A cloning and replicated in chemically competent One Shot ${ }^{\circledR}$ TOP10 Escherichia coli cells (Invitrogen) according to the manufacturer's protocol. 
The gene was then cloned into the expression vectors pET100/D-TOPO (fusing 6x His tag and Xpress $^{\mathrm{TM}}$ epitope to the N-terminus of cloned gene product) and pET151/D-TOPO (fusing 6x His tag and V5 epitope to the N-terminus of cloned gene product) using a forward primer 5'-CAC CAT GAG CAA TCT ACC TA-3' (for both vectors) and a reverse primer 5'-AGC TTG AAC TTC CAC AG-3' (pET100/D-TOPO, gene specific STOP codon removed) or 5'-TTAAGC TTG AAC TTC CAC AG-3' (pET151/D-TOPO, gene specific STOP codon maintained), with a blunt-end generating proofreading polymerase Phusion ${ }^{\mathrm{TM}}$ (annealing at $55^{\circ} \mathrm{C}, 30$ cycles). The insert region of the construct was fully sequenced to confirm the gene identity and used to transform competent cells BL21 Star ${ }^{\mathrm{TM}}$ (DE3) One Shot ${ }^{\mathbb{B}}$ Chemically Competent Escherichia coli cells (Invitrogen) according to the manufacturer's protocol.

The gene sequence $A A H 1$ from $S$. cerevisiae (GeneID: 855581 , no introns) was cloned by analogous procedure first to the pDrive vector using touchdown PCR (annealing at $64^{\circ} \mathrm{C}-58^{\circ} \mathrm{C}, 30$ cycles, added 5\% Triton X-100) with primers 5'-CGA AAC TGC ACT GAA ATG GCG CA-3' (forward) and 5'-CGT GAA ATA CAA AAG GTC CAG C-3' (reverse) and then to pET100/D-TOPO and $\mathrm{pET} 151 / \mathrm{D}-\mathrm{TOPO}$ (annealing at $56^{\circ} \mathrm{C}, 30 \mathrm{cycles}, 5 \%$ Triton X-100) with a forward primer $5^{\prime}$-CAC CAT GGT TTC TGT GGA GT-3' and a reverse primer 5'-ATG CGA ATA TTT AGT GAC TAC TT3' (pET100/D-TOPO) or 5'-CTA ATG CGA ATA TTT AGT GAC TAC TTC GT-3' (pET151/DTOPO) as above.

\section{Cloning of putative adenosine deaminase gene from Arabidopsis thaliana}

Total RNA was isolated from one-week-old seedlings of Arabidopsis thaliana ecotype Col0 using Trizol reagent (Invitrogen) and reverse transcribed using RevertAid ${ }^{\text {TM }}$ H Minus M-MuLV reverse transcriptase and oligo(dT) $)_{18}$ primer (Fermentas, Vilnius, Lithuania).

From cDNA, the gene sequence At4g04880 (GeneID: 825826; the genomic gene contains 10 introns) was amplified and cloned into pDrive vector (annealing at $57^{\circ} \mathrm{C}, 30$ cycles, added $10 \%$

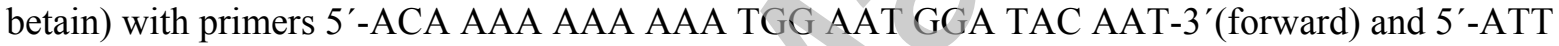
ACA ATC AAT ATT CGA GAT GAA TGT TAT-3' (reverse) and then to pET100/D-TOPO and pET151/D-TOPO vectors (annealing at $60^{\circ} \mathrm{C}, 30$ cycles) with a forward primer 5 '-CAC CAT GGA ATG GAT ACA ATC ACT G-3' and a reverse primer 5'-AAC GTG CTC TGG CGA GGC3'(reverse) (pET100/D-TOPO) or 5'-CTAAACGTGCTCTGGCGAG-3' (pET151/D-TOPO) by the same procedure as for the yeast adenine deaminase genes.

\section{Expression and purification of recombinant proteins}

Protein expression in $E$. coli cells BL21 Star ${ }^{\mathrm{TM}}$ (DE3) was induced by $0.2 \mathrm{mM}$ IPTG using a cell culture of $\mathrm{OD}_{600} 0.6$ maintained at $18^{\circ} \mathrm{C}$ overnight in LB medium containing $1 \%$ glucose and 100 $\mu \mathrm{g} / \mathrm{ml}$ of antibiotics (ampicillin for SPBC1198.02 and carbenicillin for Aah1p and At4g04880).

Recombinant proteins were purified on Ni-NTA agarose (Qiagen) using modified manufacturer's miniprep protocol for purification of $6 \mathrm{x}$ His-tagged proteins from $E$. coli under native conditions. Glycerol was added as a stabilizing agent to all buffers used throughout the purification, i.e. lysis buffer $\left(50 \mathrm{mM} \mathrm{NaH}_{2} \mathrm{PO}_{4}, 300 \mathrm{mM} \mathrm{NaCl}, 10 \mathrm{mM}\right.$ imidazole, $0.5 \%$ Triton X-100, $10 \%$ glycerol, $\mathrm{pH}$ 8.0 ), washing buffer (the same composition without Triton X-100) and elution buffer ( $50 \mathrm{mM}$ $\mathrm{NaH}_{2} \mathrm{PO}_{4}, 300 \mathrm{mM} \mathrm{NaCl}, 300 \mathrm{mM}$ imidazole, $20 \%$ glycerol, $\mathrm{pH}$ 8.0).

Cells overexpressing the studied enzymes were harvested by centrifugation $(5,000 \mathrm{~g}, 10 \mathrm{~min})$, resuspended in lysis buffer in volume ratio of 5\% to the original culture volume for SPBC1198.02 and $2.5 \%$ for Aah $1 \mathrm{p}$ and At $4 \mathrm{~g} 04880$. The cells were placed in 1.5-ml Eppendorf tubes and broken by three-times repeated freezing in liquid nitrogen and thawing at $42^{\circ} \mathrm{C}$.

Conditions for protein purification were optimized for $1.2 \mathrm{ml}$ of cell extract per tube for each protein as follows: SPBC1 198.02, binding with $0.3 \mathrm{ml}$ of $50 \%$ Ni-NTA slurry, elution with $0.15 \mathrm{ml}$ of the elution buffer; Aah1p and At4g04880, binding with $0.15 \mathrm{ml} 50 \%$ Ni-NTA slurry, elution with $0.075 \mathrm{ml}$ of the elution buffer. Optionally, the recombinant proteins were concentrated using an Amicon Ultra-4 centrifugation device with a $10-\mathrm{kDa}$ cut-off (Millipore, Cork, Ireland) to the concentration of about $30 \mathrm{mg} / \mathrm{ml}$ and stored at $4{ }^{\circ} \mathrm{C}$. Protein purity was checked by SDS-PAGE performed on a slab gel (10\%) in Tris-glycine running buffer [34]. Before application, samples were heated at $95^{\circ} \mathrm{C}$ for $10 \mathrm{~min}$ in the presence of $1 \%$ SDS and $1 \% 2$-mercaptoethanol. PageRuller ${ }^{\mathrm{TM}}$ 
unstained protein ladder (Fermentas) was used as a molecular mass marker. Gels were stained for proteins with Coomassie Brilliant Blue R-250.

\section{Enzyme activity assay}

Interactions of the enzymes with substrates were monitored by absorption changes in the range of 200$500 \mathrm{~nm}$ using Agilent (HP) 8345 diode array spectrophotometer (Agilent Technologies, Santa Clara, CA, USA) in a temperature controlled cell with magnetic stirring. Molar absorption coefficients of substrates and products were determined experimentally from reference compounds and used for the calculations of product concentration as shown below for the substrates adenine and adenosine. The assay method is based on a published protocol for adenine deaminase [35].

Adenine deaminase activity was assayed as an increase in hypoxanthine concentration (calculated from its absorption at $240 \mathrm{~nm}-\varepsilon^{\text {Hyp }}{ }_{240} 8,850 \mathrm{M}^{-1} \mathrm{~cm}^{-1}$ ), with $0.067 \mathrm{mM}$ adenine as substrate, in $0.2 \mathrm{M}$ potassium phosphate buffer, $\mathrm{pH} 6.7$, at $33{ }^{\circ} \mathrm{C}$. The reaction was started by the addition of substrate. Adenine itself has an absorption maximum at $260 \mathrm{~nm}\left(\varepsilon^{\mathrm{Ade}}{ }_{265} 11,050 \mathrm{M}^{-1} \mathrm{~cm}^{-1}\right)$ and thus it contributes to the total absorption at $240 \mathrm{~nm}\left(\varepsilon^{\mathrm{Ade}}{ }_{240} 5,850 \mathrm{M}^{-1} \mathrm{~cm}^{-1}\right)$. The concentration of a product released from the enzymatic reaction was therefore calculated as $[\mathrm{P}]=\Delta \mathrm{A}_{240} /\left(\varepsilon_{240}^{\mathrm{P}}-\varepsilon_{240}^{\mathrm{S}}\right)$, where $\Delta \mathrm{A}_{240}$ is the linear increase in absorbance during given time period, $\varepsilon_{240}^{\mathrm{P}}$ the molar absorption coefficient of product and $\varepsilon_{240}^{\mathrm{S}}$ the molar absorption coefficient of substrate, all at $240 \mathrm{~nm}$.

The activity of adenosine deaminase was determined as an increase in inosine concentration at 240 $\mathrm{nm}\left(\varepsilon_{240}^{\mathrm{Ino}} 12,930 \mathrm{M}^{-1} \mathrm{~cm}^{-1}\right)$ using the same method as above $(0.067 \mathrm{mM}$ adenosine as substrate, $0.2 \mathrm{M}$ potassium phosphate buffer, $\left.\mathrm{pH} 7,37{ }^{\circ} \mathrm{C}\right)$, with the correlation to the adenosine absorption at $240 \mathrm{~nm}$ $\left(\varepsilon_{240}^{\text {Ado }} 5,740 \mathrm{M}^{-1} \mathrm{~cm}^{-1}\right)$.

The activity with AMP/ATP was assayed as an increase in IMP/ITP concentration at $240 \mathrm{~nm}$ $\left(\varepsilon^{\mathrm{IMP}}{ }_{240} 6,670 \mathrm{M}^{-1} \mathrm{~cm}^{-1}, \varepsilon^{\mathrm{ITP}}{ }_{240} 6,060 \mathrm{M}^{-1} \mathrm{~cm}^{-1}\right)$ as above using $\varepsilon_{240}^{\mathrm{S}}$ found experimentally: AMP - 3,390 $\mathrm{M}^{-1} \mathrm{~cm}^{-1}$ and ATP - 3,080 $\mathrm{M}^{-1} \mathrm{~cm}^{-1}$.

The activity with cytokinins was assayed as a production of hypoxanthine (or inosine for ribosides) by the same method as above with the following $\varepsilon_{240}$ found experimentally: $N^{6}$-isopentenyladenine 3,920 $\mathrm{M}^{-1} \mathrm{~cm}^{-1}, N^{6}$-isopentenyladenosine - 3,780 $\mathrm{M}^{-1} \mathrm{~cm}^{-1}, N^{6}$-isopentenyladenine 9-glucoside - 3,840 $\mathrm{M}^{-1} \mathrm{~cm}^{-1}, N^{6}$-methyl-isopentenyladenine - 3,080 $\mathrm{M}^{-1} \mathrm{~cm}^{-1}$, trans-zeatin - 7,900 $\mathrm{M}^{-1} \mathrm{~cm}^{-1}$, cis-zeatin -

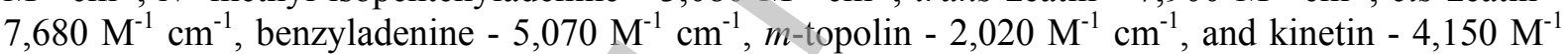
$\mathrm{cm}^{-1}$.

The activity of human adenosine deaminase with cyclin-dependent kinase inhibitors roscovitine $\left(\varepsilon_{255} 7,660 \mathrm{M}^{-1} \mathrm{~cm}^{-1}\right)$ and bohemine $\left(\varepsilon_{255} 9,000 \mathrm{M}^{-1} \mathrm{~cm}^{-1}\right)$ was assayed as an increase in the concentration of the debenzylated products absorbing at $255 \mathrm{~nm}$, i.e. 6 -amino-2-[(1-

hydroxymethyl)propyl]amino-9-isopropylpurine $\left(\varepsilon_{255} 8,800 \mathrm{M}^{-1} \mathrm{~cm}^{-1}\right)$ and 6-amino-2-(3-

hydroxypropylamino)-9-isopropylpurine $\left(\varepsilon_{255} 9,600 \mathrm{M}^{-1} \mathrm{~cm}^{-1}\right)$, respectively, using such calculations as above.

Since some cytokinin derivatives, especially $N^{6}$-benzyl substituted ones, show limited solubility in aqueous buffers, they were dissolved in DMSO prior adding to the reaction mixture. The addition of $0.7 \%$ DMSO (final concentration) decreased the rate of control reaction with adenine as a substrate to about $70 \%$.

\section{Identification of recombinant proteins by MALDI-TOF MS}

Protein samples were first resolved by SDS-PAGE (10\% separation gel) followed by CBB R-250 staining. Protein bands were excised from the gel slab, cut into small pieces and put into $0.65-\mathrm{ml}$ microtubes (Eppendorf, Hamburg, Germany). In-gel digestion by $1 \mu \mathrm{M}$ raffinose-modified trypsin [36] was performed without prior reduction/alkylation at $37 \mathrm{oC}$ for $12 \mathrm{~h}$. MALDI probes were prepared using a MSP AnchorChip 600/96 microScout target (Bruker Daltonik, Bremen, Germany) and an $\alpha$-cyano-4-hydroxycinnamic acid (CHCA) matrix [37]. Measurements were performed in the reflectron mode for positive ions on a Microflex MALDI-TOF LRF20 mass spectrometer (Bruker Daltonik) equipped with a nitrogen laser (337 nm). Mass spectra were accumulated from 100-200 shots at a laser repetition rate of $10 \mathrm{~Hz}$; the examined $\mathrm{m} / \mathrm{z}$ range was $500-4000$. The instrument was calibrated externally using a mixture of peptide standards (Bruker Daltonik). The acquired spectra were processed by flexAnalysis 2.4 and Biotools 3.0 software (Bruker Daltonik). Protein identification was achieved using the online version of the program Mascot (Matrix Science, London, UK; 
http://www.matrixscience.com); searches were performed against nonredundant protein databases (MSDB, Swiss-Prot).

\section{Circular dichroism spectra}

Circular dichroism spectra were recorded at $22^{\circ} \mathrm{C}$ using a Jasco J-810 spectrometer (Jasco, Tokyo, Japan). Data were collected from 195 to $260 \mathrm{~nm}$, at $100 \mathrm{~nm} / \mathrm{min}$, response time $1 \mathrm{~s}$ and bandwidth 2 $\mathrm{nm}$, using a $0.1 \mathrm{~cm}$ quartz cuvette containing the protein in $0.1 \mathrm{M}$ potassium phosphate buffer, $\mathrm{pH} 7.0$. Collected data were expressed in terms of the mean residue ellipticity $\left(\Theta_{M R E}\right)$ using the equation: $\Theta_{M R E}$ $=\Theta_{o b s} . M_{\mathrm{w}} \cdot 100 /$ (n.c.l), where $\Theta_{o b s}$ is the observed ellipticity in degrees, $M_{w}$ is the protein molecular weight, $n$ is number of residues, $l$ is the cell path length, $c$ is the protein concentration and the factor 100 originates from the conversion of the molecular weight to $\mathrm{mg} / \mathrm{dmol}$.

\section{Identification of reaction products by LC-MS}

A hybrid Q-Tof micro mass spectrometer (Waters MS Technologies, Manchester, UK) was used for the high-resolution identification and confirmation of enzyme-generated products. The reaction mixture for identification of the product of Schizosaccharomyces pombe adenine deaminase containing $178 \mathrm{nkat} / \mathrm{ml}$ of the enzyme and $0.1 \mathrm{mM}$ substrate in $0.2 \mathrm{M}$ potassium phosphate buffer, $\mathrm{pH}$ 6.7, was incubated at $33{ }^{\circ} \mathrm{C}$ (incubation time $5 \mathrm{~h}$ for adenine, $16 \mathrm{~h}$ for cytokinin as substrate). The reaction mixture of human adenosine deaminase with cytokinins and cyclin-dependent kinase inhibitors contained $5.1 \mu \mathrm{kat} / \mathrm{ml}$ of the enzyme and $0.01 \mathrm{mM}$ substrate in $0.2 \mathrm{M}$ potassium phosphate buffer, $\mathrm{pH} 7.0$, was incubated at $37^{\circ} \mathrm{C}$ for $24 \mathrm{~h}$. Standard samples of the substrates and products (the same concentrations as for the reaction mixtures) were first dissolved in DMSO and then in the corresponding reaction buffer (the final DMSO concentration was 1\%). Aliquots of $20 \mu \mathrm{l}$ were taken for analysis.

The measurement was performed in connection with HPLC analysis on an Alliance separation module 2965 and equipped with a photodiode array detector 2996 (Waters) using a reversed-phase column Symmetry C18 (150 mm x $2.1 \mathrm{~mm}$ i.d., $5 \mu \mathrm{m}$, Waters) and a post-column splitting of 1:1. Following the injection, analytes were eluted with a 25-min binary linear gradient $(0 \mathrm{~min}, 2 \% \mathrm{~B} ; 2-25$ $\mathrm{min}, 90 \% \mathrm{~B}$; flow-rate of $0.25 \mathrm{ml} / \mathrm{min}$; column temperature of $30^{\circ} \mathrm{C}$ ) of $15 \mathrm{mM}$ ammonium formate $(\mathrm{pH} 4.0, \mathrm{~A})$ and methanol (B). Electrospray ionization in the positive ion mode was performed using the following parameters: source block/desolvation temperature, $100^{\circ} \mathrm{C} / 350^{\circ} \mathrm{C}$; capillary/cone voltage, $2,500 / 25 \mathrm{~V}$; and spray/cone gas flow $\left(\mathrm{N}_{2}\right), 50 / 500 \mathrm{l} / \mathrm{h}$. In the full-scan mode, data were acquired in the mass range $\mathrm{m} / \mathrm{z} 50$ to 1000 , with a cycle time of $33 \mathrm{~ms}$, a scan time of $2.0 \mathrm{~s}$, and collision energy of 4 $\mathrm{V}$. For the exact mass determination experiments, a lock spray was used for external calibration with a mixture of $0.1 \mathrm{M} \mathrm{NaOH} / 10 \%$ formic acid ( $\mathrm{v} / \mathrm{v})$ and acetonitrile (1:1:8 by volume) as a reference. Accurate masses were calculated and used for the determination of the elementary composition and structure of the analytes with a fidelity of $5 \mathrm{ppm}$.

\section{RESULTS}

\section{Cloning and expression of adenine/adenosine deaminase genes}

Adenine/adenosine deaminases hydrolyze $N^{6}$-amino group of adenine/adenosine, but they may act also on other substrates such as purines containing chlorine, methoxy or methylamine in the position 6 [46]. In this context, a paper describing enzymatic degradation of $N^{6}$-furfuryladenine (known as a cytokinin named kinetin) by Schizosaccharomyces pombe [39] has been particularly interesting, because yeast do not possess the enzyme cytokinin dehydrogenase (EC 1.5.99.12), commonly metabolizing cytokinins in plants [40]. As S. pombe is known to contain adenine deaminase [3], we decided to test the hypothesis that adenine deaminases and possibly also adenosine deaminases may act on cytokinin bases and ribosides, respectively. Since it is difficult to purify these enzymes their native sources, two yeast adenine deaminase genes and a homologous gene from Arabidopsis thaliana have been chosen for cloning and functional expression to obtain active recombinant enzymes.

Translated sequences of the studied yeast genes share $45.7 \%$ identity and $61.1 \%$ similarity as calculated by the BioEdit software 7.0.5.3 on the BLOSUM 62 matrix [41], while to the A. thaliana 
enzyme they show only about $16 \%$ identity and $31 \%$ similarity. When comparing these protein sequences to mammalian adenosine deaminase from cow and human, the identity is about $20 \%$ and similarity about $40 \%$. Despite the low similarity, all important active site residues deduced from the structure of bovine adenosine deaminase [20] are conserved as shown in the protein sequence alignment in Figure 1A. The corresponding $A$. thaliana gene product contains an adenosine/AMP conserved domain cd00443 (different from the domain cd01320 present in the yeast enzymes studied in this work) that is also found in some prokaryotic and eukaryotic enzymes annotated as ADA, adenosine/AMP deaminase or ADA like proteins.

Interestingly, there is a part of the amino acid sequence of $S$. pombe adenine deaminase, which shows a notable homology to CHASE domain of the cytokinin receptor CRE1/WOL/AHK4. This receptor is responsible for cytokinin signal perception in Arabidopsis thaliana and interacts with the hormone via the CHASE domain [42]. As identified by the NCBI BLAST search (blastp), the CHASE domain (amino acid residues 198-411 of CRE1/WOL/AHK4) shows $25 \%$ identity and $41 \%$ similarity in the stretch of 120 residues (199-320) to the residues 153-275 of SPBC1198.02 (Figure 1B). This homology was found for the enzyme from S. pombe, but not for the other studied proteins.

All three proteins of interest were obtained by cloning the corresponding genes into $\mathrm{pET}$ vectors followed by IPTG-inducible expression in E. coli. At higher temperatures than $18{ }^{\circ} \mathrm{C}$, the recombinant protein was localized to inclusion bodies. As shown in Figure 2, homogeneous preparations of all three enzymes from $E$. coli cell extracts were obtained by single-step affinity purification on Ni-NTA agarose. The binding and elution conditions were optimized for each protein as described in Material and Methods. Although specific activities of both expression products were the same, protein constructs carrying an additional 3'-translated overhanging sequence from the pET100/D-TOPO vector (see Table 1) fused to the protein C-terminus were much more resistant to proteolytic degradation in E. coli cell extracts than the proteins lacking the extended C-terminal sequence and were therefore used throughout the study.

Protein expression was evaluated by MALDI-TOF peptide mass fingerprinting (Supplement 1) performed after SDS-PAGE and in-gel digestion. The recombinant proteins were unambiguously assigned to the UniProtKB/Swiss-Prot protein accession numbers P53909 (S. cerevisiae Aah1p), Q9P6I7 (S. pombe SPBC1198.02), and Q8LPL7 (A. thaliana ADA). The corresponding sequence coverage values were 65, 40 and 69\%, respectively, probability-based MOWSE scores (Mascot search) were in the range 121-292, RMS error was below $50 \mathrm{ppm}$.

Far-UV circual dichroism spectra were used to assess the proper folding and secondary structure of studied recombinant proteins. Comparison of the measured spectra demonstrated that all tested aminohydrolase enzymes are correctly folded. All proteins showed spectra typical of a predominantly $\alpha$-helix conformation with two negative features at $\sim 221$ and $208 \mathrm{~nm}$ [43]. No significant difference between the spectra of all three aminohydrolases was found (Supplement 2), which suggests that secondary structure content of all tested enzymes is very similar.

\section{Biochemical characterization of the recombinant proteins}

Activity of purified proteins was stable for one to two weeks when stored at $4{ }^{\circ} \mathrm{C}$ in concentrations above $10 \mathrm{mg} / \mathrm{ml}$ with addition of $20 \%$ glycerol. Prolonged storage in solution was possible at $-20{ }^{\circ} \mathrm{C}$ with $50 \%$ glycerol, at $-80{ }^{\circ} \mathrm{C}$ with $10-20 \%$ glycerol or as a lyophilized powder. After dissolving the lyophilized enzymes, however, the activity decreased significantly within 3-4 h. Thanks to the straightforward purification, all further studies were done with fresh enzyme preparations. In general, the activity was highest in potassium phosphate buffers, decreasing to about $75 \%$ in $\mathrm{Tris} / \mathrm{HCl}$ and to $30 \%$ in MOPS (data for $S$. pombe adenine deaminase). Phosphate buffer was therefore used for all studies.

A comparison of general biochemical properties of the enzymes from S. cerevisiae, S. pombe and A. thaliana with those published for human adenosine deaminase (ADA1, [44]) is shown in Table 1. Compared to human ADA1, the yeast enzymes have a similar $\mathrm{pH}$ optimum and $K_{\mathrm{m}}$ value for the best substrate. Their $k_{\text {cat }}$ values, however, are much smaller than that of the human enzyme. The $k_{\text {cat }}$ value of $A$. thaliana protein is extremely low and it is not clear if the protein is really a deaminase enzyme.

\section{Identification of reaction products by HPLC-MS}


Reaction products of the studied enzymes were analyzed and identified using standards on HPLC equipped with UV and MS detectors (Figure 3). Degradation of adenine $(m / z 136)$ by

Schizosaccharomyces pombe adenine deaminase showed the expected product hypoxanthine with a typical UV absorption maximum at $250 \mathrm{~nm}$ and $\mathrm{m} / z 137 \mathrm{Da}$. Hypoxanthine was also confirmed as a product of the degradations of cytokinins isopentenyladenine ( $\mathrm{m} / \mathrm{z} 204)$ and $m$-topoline $(\mathrm{m} / \mathrm{z} 242)$. The side-chain cleavage product, supposedly an amine was not detected in the chromatogram. Further experiment with a standard compound benzylamine showed that amines eluted near the dead volume and thus no identification was possible.

Analysis of the reaction mixture of human adenosine deaminase with cytokinins did not show hypoxanthine or any other detectable products. However, when the reaction with a cyclin-dependent kinase inhibitor roscovitine $(\mathrm{m} / \mathrm{z} 355)$ was analyzed, an unexpected product was detected, having the molecular mass less by $1 \mathrm{Da}$ than 6-hydroxy-2-[(1-hydroxymethyl)propyl]amino-9-isopropylpurine that would have been expected as the product if the reaction had proceeded as for the $S$. pombe adenine deaminase. Using accurate mass determination, the compound was identified as 6-amino-2[(1-hydroxymethyl)propyl]amino-9-isopropylpurine, $\mathrm{m} / \mathrm{z} 265$. Since it was possible to obtain the compound from the stock in our laboratory, the identification was further verified by comparing retention time and UV spectrum (maxima at 222, 256 and $295 \mathrm{~nm}$ ). Another cyclin dependent kinase inhibitors, olomoucine II $(\mathrm{m} / \mathrm{z} 371)$, having the purine part of the molecule identical to that of roscovitine, gave the same hydrolytic product. Analogous product identification using an available reference compound was performed for the reaction of bohemine $(\mathrm{m} / \mathrm{z} 341)$ that was hydrolyzed to 6amino-2-(3-hydroxypropylamino)-9-isopropylpurine ( $\mathrm{m} / \mathrm{z} 251$, UV spectrum maxima at 222, 255 and $296 \mathrm{~nm})$. Hydrolysis of olomoucine $(\mathrm{m} / \mathrm{z} 299)$ gave 6-amino-2-(2-hydroxyethylamino)-9-methylpurine $(\mathrm{m} / \mathrm{z} 209)$ that was identified by accurate mass determination (unfortunately a reference compound for the hydrolytic product of olomoucine was not available). The expected side-chain cleavage product benzylalcohol was also searched for with a standard compound, but as it eluted near the dead volume in the chromatogram, no clear identification was possible.

Based on the above experimental data, we propose reaction schemes for yeast adenine deaminase and human adenosine deaminase as shown in Figure 4.

\section{Activity assays with adenine/adenosine, cytokinins and cyclin-dependent kinase inhibitors}

Adenine/adenosine deaminase activity of purified enzyme preparations can be simply assayed, apart from TLC and radioactivity measurements [45], by monitoring UV spectra reflecting the changes in substrate or product hypoxanthine/inosine concentrations [3, 20,35]. The latter option was preferable, since it could be presumably used also for other substrates than adenine/adenosine that do not release ammonia, but primary amines when metabolized by the enzyme.

UV absorption spectra of adenine show a maximum at $260 \mathrm{~nm}$, which is close to hypoxanthine maximum at $250 \mathrm{~nm}$ (Figure 5C), but adenine shows far less absorption at $240 \mathrm{~nm}$, where its conversion to hypoxanthine can be monitored [20], Figure 5A. The same method can be applied to adenosine/inosine, AMP/IMP and ATP/ITP that show similar shape of absorption spectra with slightly different molar absorption coefficients (see Material and Methods). The other released product ammonia, shows negligible contribution to the total absorption [46].

Deamination of cytokinins that have the main absorption band shifted to about $269 \mathrm{~nm}$ and release hypoxanthine or inosine can be also monitored at $240 \mathrm{~nm}$ (Figure 5B,C). The other respective products, $N^{6}$-sidechain amines, have negligible contributions to the $240 \mathrm{~nm}$ absorption.

Human adenosine deaminase cleaves adenosine producing spectral changes similar to those of the yeast adenine deaminases acting on adenine and its activity can be assayed as the production of inosine at $240 \mathrm{~nm}$ (Figure 6A). The enzyme, however, does not cleave cytokinins at all. Interaction of human adenosine deaminase with cyclin-dependent kinase inhibitors showed spectral changes that were completely different from those of adenine/adenosine reactions and cytokinin reactions of the yeast enzymes. The nature of these changes was fully understood only after identification of the reaction products by HPLC coupled to Q-TOF mass spectrometer as described in the previous paragraph. As shown in Figure 6B, the spectrum of hydrolyzed roscovitine shows a significant increase in the region of 250-260 $\mathrm{nm}$ that reflects the release of the hydrolytic product 6-amino-2-[(1hydroxymethyl)propyl]amino-9-isopropylpurine with a characteristic absorption maximum at $255 \mathrm{~nm}$ (Figure 6C). On the basis of determining the molar absorption coefficient of this compound that was 
synthesized (see Materials and Methods), it was possible to assay the rate of the hydrolysis of roscovitine and olomoucine II that gives the same product. The same approach was used to determine the rate of enzymatic hydrolysis of bohemine to 6-amino-2-(3-hydroxypropylamino)-9isopropylpurine. As the hydrolytic products of the other tested compound olomoucine was not available, it was not possible to assay the activity directly, but only estimate its values using the molar absorption coefficient of the product of bohemine that is supposed to show similar absorption.

\section{Reaction rates of adenine/adenosine deaminases with cytokinins and cytokinin derivatives} Of the three recombinant proteins prepared in this work, only the yeast enzymes were capable of hydrolytical cleavage of cytokinins. Cyclin-dependent kinase inhibitors derived from cytokinins, but not the cytokinins themselves, were also substrates of human ADA1. Relative reaction rates of all studied enzymes with various substrates are shown in Table 2. The yeast enzymes both showed substrate specificity that unambiguously confirms their classification as adenine deaminases, despite being annotated in databases as adenosine deaminases (e.g. the entries P53909 and Q9P6I7 in UniProtKB/Swiss-Prot). Adenine was by far the best substrate, followed by AMP and ATP, while the cleavage of adenosine and cytokinins proceeded at rates of several percent of that of adenine. The hydrolysis of the $N^{6}$-sencondary amino group of cytokinins produced hypoxanthine/inosine molecule and an amine from the cytokinin side-chain as described above (Figure 4).

The enzyme from $A$. thaliana, in addition to its low activity, did not show a clear preference for either adenine, adenosine, AMP or ATP, and did not cleave cytokinins at all.

Human adenosine deaminase showed substrate specificity that clearly differed from the above enzymes. The highest activity was found with adenosine, followed by 10 -fold lower values obtained with adenine, AMP and ATP. Surprisingly, the enzyme did not cleave cytokinins, but showed reaction rates similar to adenine and ATP/AMP with the derivatives of cytokinins bearing hydrophobic chains at $\mathrm{C} 2$ and $\mathrm{C} 9$ that are known as effective cyclin-dependent kinase inhibitors. As found by HPLC-MS analysis of the products, the $N^{6}$-secondary amino group of these compounds was cleaved in an opposite manner (i.e. at its exo-side) than in the case of yeast adenine deaminase reaction with cytokinins, leaving the primary amino group on the purine ring and assumedly releasing benzylalcohol derived from the $N^{6}$ side-chain (Figure 4).

\section{DISCUSSION}

In yeast, adenine deaminase is responsible for the metabolic salvage of purine compounds. AAH1 gene in Saccharomyces cerevisiae is strongly downregulated when the yeast enters quiescence under nutrient limiting conditions. Downregulation is maintained via proteasome- and SCF-dependent degradation [47]. As shown in this work, $k_{\text {cat }}$ values of the yeast enzymes are about 50-fold lower than that of human ADA1 [44], but probably still sufficient for the metabolic function. The data obtained in this work with the recombinant adenine deaminase from Schizosaccharomyces pombe are in agreement with the older report describing enzymatic degradation of kinetin by this yeast [39]. This protein exhibits a partial amino acid sequence similarity to the CHASE domain of cytokinin receptor that may account for its ability to bind and hydrolyze not only kinetin but also other cytokinins and cytokinin derivatives, albeit at lower rates than its natural substrate adenine (Table 2). It is not likely, however, that the yeast adopts a specific metabolic pathway for cleaving cytokinins, since it does not commonly interact with cytokinin-producing systems.

The protein from Arabidopsis thaliana encoded by the gene At4g04880 shows very low activity without obvious substrate preference for adenine, adenosine, AMP or ATP. The protein may perform different functions than metabolism of purine compounds, which in plant is believed to be controlled by adenosine kinase [24]; perhaps it may be involved in plant defense. Recent data from GENEVESTIGATOR [48] shows that the expression of the gene $A t 4 g 04880$ is strongly induced by biotic stress (probeset 255299_at, array name Agro_inf_rep_3). The gene expression is 10-fold upregulated in mature Arabidopsis siliques infected with Agrobacterium tumefaciens. As found in rice, genes coding for deoxycytidine deaminase $(O s 07 g 14150)$ and AMP deaminase $(O s 05 g 28180)$ are as well upregulated during an infection with the fungal pathogen Magnaporthe grisea and may be involved in RNA-editing [49]. These proteins, however, do not share significant sequence homology 
with the product of the gene At4g04880 studied in this work, the former belonging to cytidine deaminase family and the latter to AMP deaminase family that includes the embryonic factor FAC1 [50].

Some synthetic cytokinin derivatives exhibit anticancer properties due to their ability to inhibit cyclin-dependent kinases [26] and currently they undergo testing in clinical trials as drugs for treatment of some types of cancers and glomerulonephritis, others such as kinetin find application in skin protective cosmetics as delay ageing of human fibroblasts [27] and protect against oxidative damage of DNA [28]. Our results show that in humans, the high activity of adenosine deaminase (ADA1) may attenuate the level of some of the active compounds and thus compromise their physiological or therapeutic effect. These compounds are hydrolyzed (debenzylated) via different reaction mechanism than the natural substrate adenosine and at a lower rate, but due to very high turnover number of the enzyme, the rate may be still quite significant. Debenzylation of bohemine by mouse liver microsomes supplemented with NADPH was already described as one of the main biotransformation routes [30]. The different product specificity of yeast and human adenine/adenosine deaminases when acting on secondary amino group may be similar to the case of polyamine oxidases. Plant and bacterial polyamine oxidases oxidize the carbon on the endo-side of the N4-nitrogen of spermidine and spermine, while animal polyamine oxidases and yeast (Saccharomyces cerevisiae) spermine oxidase oxidize the carbon on the exo-side of the N4-nitrogen [51].

We suggest that the survey of potential biologically active compounds derived from adenine should include also an assessment of the hydrolytic cleavage by ADA1 using the methods described in this work. As none of the enzymes studied in this work was not capable of cleaving $\mathrm{N}$ -

methylisopentenyladenine and the hydrolytic cleavage of a tertiary amino group is highly unlikely, we also suggest that additional methylation of these compounds at N6 may fully prevent the degradation by deaminases.

\section{Acknowledgements}

This work was supported in part by the grants MSM 6198959216 from the Ministry of Education, Youth and Sports and 522/06/0022 from the Czech Science Foundation. Authors thank Radka Chaloupková from Loschmidt Laboratories at the Masaryk University Brno for measuring circular dichroism spectra.

\section{REFERENCES}

1 Maier, S.A., Galellis, J.R and McDermid, H.E. (2005) Phylogenetic analysis reveals a novel protein family closely related to adenosine deaminase. J. Mol. Evol. 61, 776-794

2 Pospiśilová, H. and Frébort, I. (2007) Aminohydrolases acting on adenine, adenosine and their derivatives. Biomedical Papers 151, 3-10

3 Ribard, C., Rochet, M., Labedan, B., Daignan-Fornier, B., Alzari, P., Scazzocchio, C. and Oestreicher, N. (2003) Sub-families of of $\alpha / \beta$ barrel enzymes: A new adenine deaminase family. J. Mol. Biol. 334, 1117-1131

4 Pickard, M.A. (1975) Purification and some properties of the soluble and membrane-bound adenosine deaminases of Micrococcus sodonensis ATCC 11880 and their distribution within the family Micrococcacea. Can. J. Biochem. 53, 344-353

5 Lupidi, G., Marmocchi, F. and Cristalli G. (1998) Inhibition studies on membrane adenosine deaminase from human placenta. Biochem. Mol. Biol. Int. 46, 1071-1080

6 Nygaard, P. (1978) Adenosine deaminase from Escherichia coli. In Methods in Enzymology, vol. 51, Purine and Pyrimidine Nucleotide Metabolism (Hoffee, P. A. and Jones M. E., eds.), pp. 508-512, Academic Press, New York

7 Jun, H.K., Kim, T.S. and Yeeh, Y. (1994) Purification and characterization of an extracellular adenosine deaminase from Nocardioides sp. J-326TK. Biotechnol. Appl. Biochem. 20, 265-277 
8 Jun, H. K., Kim, T.S. and Sakai, T. (1991) Purification and characterization of extracellular adenosine deaminase from a Streptomyces sp. J. Ferment. Bioeng. 71, 6-11

9 Nygaard, P., Duckert, P. and Saxild, H.H. (1996) Role of adenine deaminase in purine salvage and nitrogen metabolism and characterisation of the ade gene in Bacillus subtilis. J. Bacteriol. $178,846-853$

10 Matsui, H., Shimaoka, M., Kawasaki, H., Takenaka, Y. and Kurahashi O. (2001) Adenine deaminase activity of the yic $\mathrm{P}$ gene product of Escherichia coli. Biosci. Biotechnol. Biochem. $65,1112-1118$

11 Wolf, J., Gerber, A.P. and Keller, W. (2002) tadA, an essential tRNA-specific adenosine deaminase from Escherichia coli. EMBO J. 21, 3841-3851

12 Keegan L.P., Leroy A., Sproul D., O'Connell M.A., Adenosine deaminases acting on RNA (ADARs): RNA-editing enzymes, Genome Biol. 5, 209

13 Hirschhorn, R. and Ratech, H. (1980) Isozymes of adenosine deaminase. In Current Topics in Biological and Medical Research, vol. 1 (Ratazzi, M.C., Scandalia J.G. and Whitt G.S., eds), pp. 132-157, Alan R. Liss, New York

14 Zavialov, A.V. and Engström, A. (2005) Human ADA2 belongs to a new family of growth factors with adenosine deaminase activity. Biochem. J. 391, 51-57

15 Van der Weyden, M.B. and Kelley W.N. (1976) Human adenosine deaminase. Distribution and properties. J. Biol. Chem. 251, 5448-5456

16 Aronow, B.J., Silbiger, R.N., Dusing, M.R., Stock, J.L., Yager, K.L., Potter, S.S., Hutton, J.J. and Wiginton, D.A. (1992) Functional analysis of the human adenosine deaminase gene thymic regulatory region and its ability to generate position-independent transgene expression. Mol. Cell. Biol. 12, 4170-4185

17 Gaspar, H.B., Bjorkegren, E., Parsley, K., Gilmour, K.C., King, D., Sinclair, J., Zhang, F., Giannakopoulos, A., Adams, S., Fairbanks, L.D., Gaspar, J., Henderson, L., Xu-Bayford, J.H., Davies, E.G., Veys, P.A., Kinnon, C. and Thrasher, A.J. (2006) Successful reconstitution of immunity in ADA-SCID by stem cell gene therapy following cessation of PEG-ADA and use of mild preconditioning. Mol. Therapy 14, 505-513

18 Persico, A.M., Militerni, R., Bravaccio, C., Schneider, C., Melmed, R., Trillo, S., Montecchi, F., Palermo, M.T., Pascucci, T., Puglisi-Allegra, S., Reichelt, K.L., Conciatori, M., Baldi, A. and Keller, F. (2000) Adenosine deaminase alleles and autistic disorder: Case-control and familybased association studies. Am. J. Med. Genet. 96, 784-790

19 Wilson, D.K., Rudolph, F.B. and Quiocho, F.A. (1991) Atomic structure of adenosine deaminase complexed with a transition-state analog: understanding catalysis and immunodeficiency mutations. Science 252, 1278-1284

20 Kinoshita, T., Nishio, N., Nakanishi, I., Sato, A. and Fujii, T. (2003) Structure of bovine adenosine deaminase complexed with 6-hydroxy-1,6-dihydropurine riboside. Acta Cryst. D 59, 299-303

21 Yabuki, N. and Ashihara, H. (1991) Catabolism of adenine nucleotides in suspension-cultured plant cells. Biochim. Biophys. Acta 1073, 474-480

22 Katahira, R. and Ashihara, H. (2006) Profiles of purine biosynthesis, salvage and degradation in disks of potato (Solanum tuberosum L.) tubers. Planta 225, 115-126

23 Guranowski, A. (1982) Purine catabolism in plants. Plant Physiol. 70, 344-349

24 Moffatt, B.A., Stevens, Y.Y., Allen, M.S., Snider, J.D., Pereira, L.A., Todorova, M.I., Summers, P.S., Weretilnyk, E. A., Martin-McCaffrey, L. and Wagner C. (2002) Adenosine kinase deficiency is associated with developmental abnormalities and reduced transmethylation. Plant Physiol. 128, 812-821 
25 Sakakibara, H. (2006) Cytokinins: Activity, biosynthesis and translocation. Annu. Rev. Plant Biol. 57, 431-449

26 Doležal, K., Popa, I., Kryštof, V., Spíchal, L., Fojtíková, M., Holub, J., Lenobel, R., Schmülling T. and Strnad, M. (2006) Preparation and biological activity of 6-benzylaminopurine derivatives in plants and human cancer cells. Bioorg. Med. Chem. 14, 875-884

27 Rattan, S.I. and Clark, B.F. (1994) Kinetin delays the onset of ageing characteristics in human fibroblasts. Biochem. Biophys. Res. Commun. 201, 665-672

28 Olsen, A., Siboska, G.E., Clark, B.F. and Rattan S.I. (1999) N(6)-Furfuryladenine, kinetin, protects against Fenton reaction-mediated oxidative damage to DNA. Biochem. Biophys. Res. Commun. 265, 499-502

29 Wang, J. and Letham D.S. (1995) Cytokinin oxidase - purification by affinity chromatography and activation by caffeic acid. Plant Sci. 112, 161-166

30 Rypka, M., Veselý, J., Chmela, Z., Riegrová, D., Červenková, K., Havlíček, L., Lemr, K., Hanuš, J., Černý, B., Lukeš, J. and Michalíková K. (2002) In vitro biotransformation of 2,6,9trisubstituted purine-derived cyclin-dependent kinase inhibitors bohemine by mouse liver microsomes. Xenobiotica 32, 1017-1031

31 Bota, A., Gella, F.J., Profilis, C., Férard, G., Hadjivassiliou, A.G., Hørder, M., Schiele, F., Segura, R. and Canalias, F. (2001) Production and certification of an enzyme reference material for adenosine deaminase 1 (BCR 647). Clin. Chim. Acta 306, 79-89

32 Bechet, J., Greenson, M. and Wiame, J.M. (1970) Mutations affecting the repressibility of arginine biosynthetic enzymes in Saccharomyces cerevisiae. Eur. J. Biochem. 12, 31-39

33 Rose, M.D. Winston, F. and Hieter, P. (1990) Methods in Yeast Genetics: A Laboratory Course Manual. Cold Spring Harbor Laboratory Press, New York

34 Laemmli, U.K. (1970) Cleavage of structural proteins during the assembly of the head of bacteriophage T4. Nature 227, 680-685

35 Kalckar, H.M. (1947) Differential spectrophotometry of purine compounds by means of specific enzymes. II. Determination of adenine compounds. J. Biol. Chem. 167, 445-459

36 Šebela, M., Štosová, T., Havliš, J., Wielsch, N., Thomas, H., Zdráhal, Z. and Shevchenko A. (2006) Thermostable trypsin conjugates for high throughput proteomics: synthesis and performance evaluation. Proteomics 6, 2959-2963

37 Thomas, H., Havliš, J., Peychl, J. and Shevchenko, A. (2004) Dried-droplet probe preparation on AnchorChipTM targets for navigating the acquisition of matrix-assisted laser desorption/ionization time-of-flight spectra by fluorescence of matrix/analyte crystals. Rapid Commun. Mass Spectrom. 18, 923-930

38 Novák, O., Tarkowski, P., Tarkowská, D., Doležal, K., Lenobel, R. and Strnad, M. (2003) Quantitative analysis of cytokinins in plants by liquid chromatography/single quadrupole mass spectrometry. Anal Chim Acta 480, 207-218

39 Guern, J., Doree, M., Leguay, J.J. and Heslot H. (1972) Enzymatic degradation of kinetin and some N6-substituted adenines in Schizosaccharomyces pombe. C. R. Acad. Sci., Ser. D 275, $377-380$

40 Galuszka, P., Spíchal, L., Kopečný, D., Tarkowski, P., Frébortová, J., Šebela, M., and Frébort I. (2008) Metabolism of plant hormones cytokinins and their function in signaling, cell differentiation and plant development. In: Studies in Natural Products Chemistry, vol. 34 (Attaur-Rahman, ed.), Elsevier, Amsterdam, in the press

41 Hall, T.A. (1999) BioEdit: a user-friendly biological sequence alignment editor and analysis program for Windows 95/98/NT. Nucl. Acids Symp. Ser. 41, 95-98 
42 Heyl, A., Wulfetangle, K., Pils, B., Nielsen, N., Romanov, G.A. and Schmülling T. (2007) Evolutionary proteomics identifies amino acids essential for ligand-binding of the cytokinin receptor CHASE domain. BMC Evol. Biol. 7, 62

43 Fasman, G.D. (1996) Circular Dichroism and the Conformational Analysis of Biomolecules, p. 740, Plenum Press, New York

44 Daddona, P.E. and Kelley W.N. (1980) Analysis of normal and mutant forms of human adenosine deaminase - a review. Mol. Cell. Biochem. 29, 91-101

45 Deeley, M.C. (1992) Adenine deaminase and adenine utilization in Saccharomyces cerevisiae. J. Bacteriol. 174, 3102-3110

46 Grammaticakis, P. (1947) Contribution a l'etude spectrale de quelques derives de l'isocyanate de phenyle. I. Absorption dans l'ultra-violet moyen des derives phenylcarbamyles de quelques amines, hydroxylamines, phenylhydrazines, cetimines et oximes. Bull. Soc. Chim. Fr. 14, 664674.

47 Escusa, S., Camblong, J., Galan, J.-M., Pinson, B. and Daignan-Fornier, B. (2006) Proteasomeand SCF-dependent degradation of yeast adenine deaminase upon transition from proliferation to quiescence requires a new F-box protein named Saflp. Mol. Microbiol. 60, 1014-1025

48 Zimmermann, P., Hirsch-Hoffmann, M., Hennig, L. and Gruissem W. (2004) GENEVESTIGATOR: Arabidopsis microarray database and analysis toolbox, Plant Physiol. $136,2621-2632$

49 Gowda, M., Venu, R.-C., Li, H., Jantasuriyarat, C., Chen, S., Bellizzi, M., Pampanwar, V., Kim, H.R., Dean, R.A., Stahlberg, E., Wing, R., Soderlund, C. and Wang, G.-L. (2007) Magnaporthe grisea infection triggers RNA variation and antisense transcript expression in rice. Plant Physiol. 144, 524-533

50 Xu, J., Zhang, H.-Y., Xie, C-H., Xue, H.-W., Dijkhuis, P. and Liu, C.-M. (2005) EMBRYONIC FACTOR 1 encodes an AMP deaminase and is essential for the zygote to embryo transition in Arabidopsis. Plant J. 42, 743-758

51 Tavladoraki, P., Rossi, M.N., Saccuti, G., Perez-Amador, M. A., Polticelli, F., Angelini R., and Federico R. (2006) Heterologous expression and biochemical characterization of a polyamine oxidase from Arabidopsis involved in polyamine back conversion. Plant Physiol. 141, 15191532 
Table 1 Biochemical characterization of studied adenine/adenosine deaminases

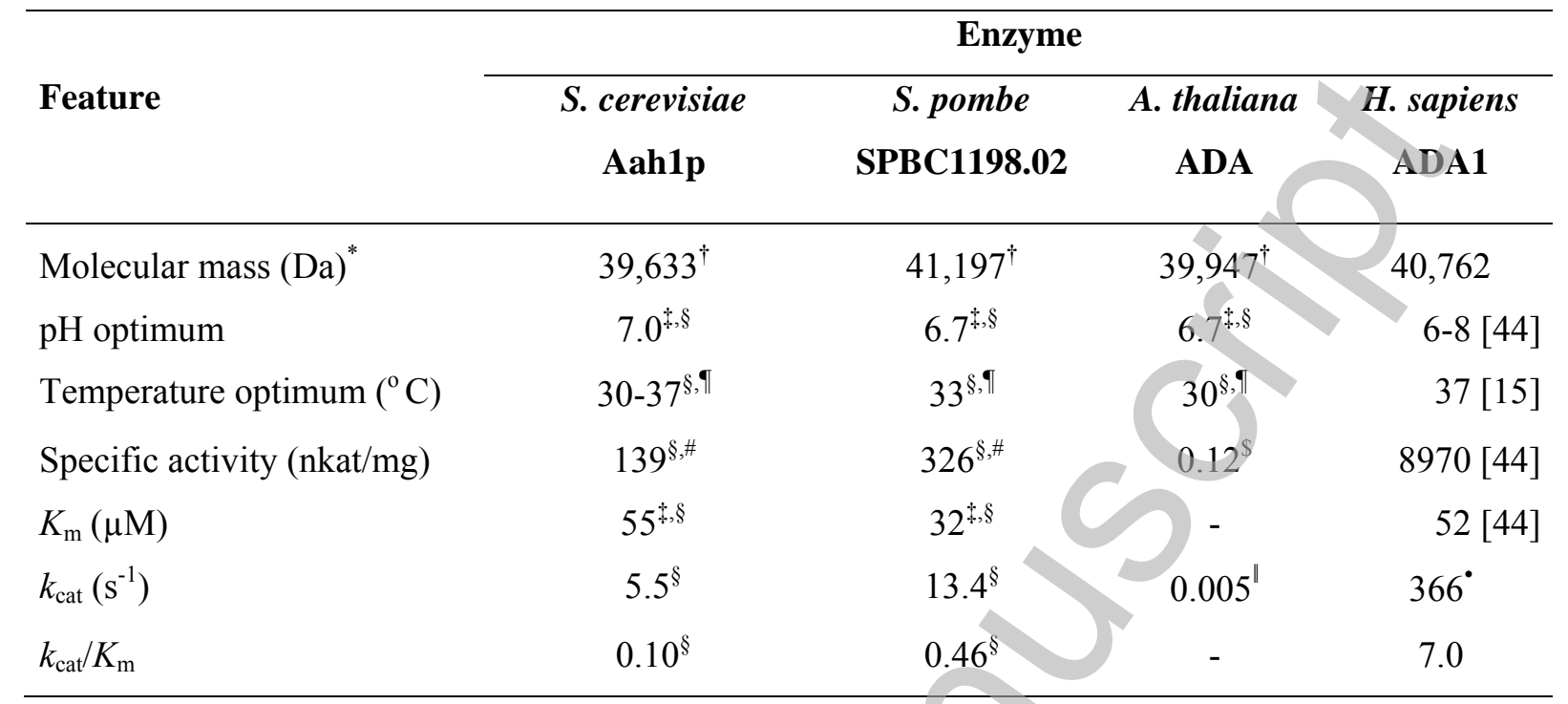

${ }^{*}$ Calculated from amino acid sequence by Bioedit 7.0.5.3 [41]; see Figure 2 for SDS-PAGE of the recombinant proteins prepared in this work

${ }^{\dagger}$ The value does not include the $6 \mathrm{x}$ His tag and Xpress ${ }^{\mathrm{TM}}$ epitope (MRGSHHHHHHGMASMTGGQQMGRDLTDDDDKDHPET of 3,875 Da) and vector 3'translated overhanging sequence (KGELNDPAANKARKEAELAAATAEQ of 2,582 Da) from pET100/D-TOPO fused to N- and C-termini of the recombinant protein, respectively

"Measured in $0.2 \mathrm{M}$ phosphate buffers, at optimum temperature

${ }^{\S}$ With adenine as a substrate

"With adenosine as a substrate, measured in $0.2 \mathrm{M}$ phosphate buffers $\mathrm{pH} 7$ at $37^{\circ} \mathrm{C}$

"Measured in $0.2 \mathrm{M}$ phosphate buffer, at optimum $\mathrm{pH}$

${ }^{\#}$ Measured with $0.067 \mathrm{mM}$ substrate in $0.2 \mathrm{M}$ phosphate buffer, at optimum $\mathrm{pH}$ and temperature

${ }^{\$}$ Measured with $0.033 \mathrm{mM}$ adenosine in $0.2 \mathrm{M}$ phosphate buffer, $\mathrm{pH} 6.7$, at $30{ }^{\circ} \mathrm{C}$

- The value was calculated from published specific activity [44] and molecular mass 
Table 2 Comparison of reaction rates of adenine/adenosine deaminases with various substrates Reaction rates were assayed with $0.067 \mathrm{mM}$ substrates as product formation at $240 \mathrm{~nm}$ except for cleavage products of cyclin-dependent kinase inhibitors that were assayed at $255 \mathrm{~nm}$ (for details see Materials and Methods) under the optimum conditions as in Table 1 (n.d. - activity not detected). All reaction mixtures contained DMSO, which was used to dissolve the substrates, at a final volume concentration of $0.7 \%$.

\begin{tabular}{|c|c|c|c|c|}
\hline \multirow{3}{*}{ Substrates } & \multicolumn{3}{|c|}{ Relative reaction rate \% } & \\
\hline & S. cerevisiae & S. pombe & A. thaliana & H. sapiens \\
\hline & Aah1p & SPBC1198.02 & ADA & ADA1 \\
\hline Adenine & 100 & 100 & $100^{*}$ & 9.9 \\
\hline Adenosine & 1.4 & 2.0 & $30^{*}$ & 100 \\
\hline AMP & 3.3 & 4.5 & $56^{*}$ & 9.1 \\
\hline ATP & 3.3 & 3.3 & $68^{*}$ & 8.8 \\
\hline$N^{6}$-Isopentenyladenine & 2.1 & 2. & n.d. & n.d. \\
\hline$N^{6}$-Isopentenyladenosine & 1.2 & 1.9 & n.d. & n.d. \\
\hline$N^{6}$-Isopentenyladenine 9-glucoside & n.d. & $1.1^{\dagger}$ & n.d. & n.d. \\
\hline$N^{6}$-Methyl-isopentenyladenine & n.d. & n.d. & n.d. & n.d. \\
\hline cis-Zeatin & 1.7 & 2.5 & n.d. & n.d. \\
\hline trans-Zeatin & 1.8 & 1.6 & n.d. & n.d. \\
\hline trans-Zeatin riboside & n.d. & n.d. & n.d. & n.d. \\
\hline trans-Zeatin 9-glucoside & n.d. & n.d. & n.d. & n.d. \\
\hline Benzyladenine & 0.7 & 3.8 & n.d. & n.d. \\
\hline Kinetin & 2.6 & 2.8 & n.d. & n.d. \\
\hline$m$-Topolin & 2.5 & 4.0 & n.d. & n.d. \\
\hline \multicolumn{5}{|l|}{ Cyclin-dependent kinase inhibitors } \\
\hline Bohemine & n.d. & n.d. & n.d. & 13.6 \\
\hline Roscovitine & n.d. & n.d. & n.d. & 6.8 \\
\hline Olomoucine & n.d. & n.d. & n.d. & $7.3^{\ddagger}$ \\
\hline Olomoucine II & n.d. & n.d. & n.d. & 7.0 \\
\hline
\end{tabular}

*Measured with $0.033 \mathrm{mM}$ substrate in $0.2 \mathrm{M}$ phosphate buffer, $\mathrm{pH} 6.7$, at $30{ }^{\circ} \mathrm{C}$

'Estimated using the molar absorption coefficient of inosine at $240 \mathrm{~nm}$ (spectral data for the product hypoxanthine 9-glucoside are not available)

*Estimated using the molar absorption coefficient of the product of bohemine at $255 \mathrm{~nm}$ (spectral data for the specific product are not available) 


\section{Figure legends}

Figure 1 Protein sequence alignment of adenine/adenosine deaminases.

(A) Multiple protein sequence alignment by ClustalW ( BioEdit software 7.0.5.3 [41]). Protein identification: Saccharomyces cerevisiae Aahlp (GeneID: 855581), Schizosaccharomyces pombe SPBC1198.02 (GeneID: 2540066), Arabidopsis thaliana ADA (GeneID: 825826), Homo sapiens ADA1 (GeneID: 100), Bos taurus ADA (GeneID: 280712). Black and gray shading identical and similar amino-acids present at that position in at least $70 \%$ of input sequences, respectively. Active site residues that were identified in the structure of Bos taurus ADA [20] are marked as follows: histidyl ligands to zinc $(*)$, substrate binding residues (s). (B) Protein sequence alignment of S. pombe adenine deaminase SPBC1 198.02 (GeneID: 2540066) and cytokinin receptor CRE1/WOL/AHK4 (GeneID: 814714) from Arabidopsis thaliana.

\section{Figure 2 SDS-PAGE of adenine/adenosine deaminases produced from pET100/D-TOPO clones}

Separation was carried out using a discontinuous buffer system according to Laemmli [34] and the protein bands were visualized by staining with CBB R-250. From the left: (1) E. coli extract before induction (10 $\mu \mathrm{g}$ of protein), (2) cytosolic fraction after induction of $S$. cerevisiae Aah1p (10 $\mu \mathrm{g}$ of protein), (3) cytosolic fraction after induction of S. pombe SPBC1198.02 (10 $\mu \mathrm{g}$ of protein), (4) cytosolic fraction after induction of $A$. thaliana ADA (9 $\mu \mathrm{g}$ of protein), (5) purified $S$. cerevisiae Aah1p, estimated molecular mass $46.0 \mathrm{kDa}(2.2 \mu \mathrm{g})$, (6) purified $S$. pombe SPBC1198.02, estimated molecular mass $48.0 \mathrm{kDa}(2 \mu \mathrm{g})$, (7) purified A. thaliana ADA, estimated molecular mass $46.5 \mathrm{Da}(1.7$ $\mu \mathrm{g})$ and $(\mathbf{M})$ molecular mass markers.

\section{Figure 3 HPLC-MS analysis of reaction products}

Schizosaccharomyces pombe adenine deaminase: (A) The following standard compounds with the indicated retention times were separated and monitored at $250 \mathrm{~nm}$ : hypoxanthine $(2.62 \mathrm{~min})$, adenine (3.24 $\mathrm{min})$ and isopentenyladenine $(22.18 \mathrm{~min})$; (B) adenine degradation by $S$. pombe adenine deaminase producing hypoxanthine $(2.60 \mathrm{~min})$; inset graphs show UV absorption and MS spectra, the substrate adenine was completely converted; $(\mathbf{C})$ isopentenyladenine degradation by the adenine deaminase producing hypoxanthine $(2.60 \mathrm{~min})$; insets show UV and MS spectra, the substrate isopentenyladenine was converted only partially $(22.20 \mathrm{~min})$.

Human adenosine deaminase: (D) Separation of roscovitine (26.46 min) and (E) 6-amino-2-[(1hydroxymethyl)propyl]amino-9-isopropylpurine (20.35) standards, inset graphs show UV absorption and MS spectra; $(\mathbf{F})$ roscovitine degradation by human adenosine deaminase producing 6-amino-2-[(1hydroxymethyl)propyl]amino-9-isopropylpurine (20.20 min); inset graph shows MS spectrum. For experimental details see Materials and Methods.

\section{Figure 4 Reaction schemes of adenine/adenosine deaminases}

(A) Hydrolysis of adenine/adenosine to hypoxanthine/inosine by adenine/adenosine deaminase, (B) hydrolytic cleavage of kinetin by yeast adenine deaminase, both occurring at the endo-side of the substrate $N^{6}$-amino group, and (C) hydrolytic exo-side cleavage of roscovitine by human adenosine deaminase ADA1.

\section{Figure 5 Spectrophotometric assays of adenine deaminase activity}

Activity assay of $S$. pombe adenine deaminase: (A) adenine hydrolysis accompanied by spectral changes due to the produced hypoxanthine; (B) $N^{6}$-isopentenyladenine hydrolysis and production of hypoxanthine, a detailed view of the spectrum region around $240 \mathrm{~nm}$ is shown in the inset; (C) UV spectra of $0.13 \mathrm{mM}$ standards: adenine (1), hypoxanthine (2), and $N^{6}$-isopentenyladenine (3); the maximum spectral difference at $240 \mathrm{~nm}$ is indicated, which was used for monitoring of hypoxanthine production. For details see the Materials and Methods section.

\section{Figure 6 Spectrophotometric assays of human adenosine deaminase activity}

Activity assay of $H$. sapiens adenine deaminase ADA1: (A) adenosine hydrolysis accompanied by spectral changes due to the produced inosine; (B) spectral changes due to the cleavage of roscovitine; 
(C) UV spectra of $0.02 \mathrm{mM}$ standards: roscovitine (1) and 6-amino-2-[(1-

hydroxymethyl)propyl]amino-9-isopropylpurine (2); the maximum spectral difference at $255 \mathrm{~nm}$ is indicated, which was used for monitoring of product formation. For details see the Materials and Methods section. 


\section{A}

S. cerevisiae Aah1p

S. pombe SPBC1198.02

A. thaliana ADA

B. taurus ADA

H. sapiens ADA1

S. cerevisiae Aah1p

S. pombe SPBC1198.02

A. thaliana ADA

B. taurus ADA

H. sapiens ADA1

S. cerevisiae Aah1p

s. pombe SPBC1198.02

A. thaliana ADA

B. taurus ADA

H. sapiens ADA1

S. cerevisiae Aah1p

S. pombe SPBC1198.02

A. thaliana ADA

B. taurus ADA

H. sapiens ADA1

S. cerevisiae Aah1p

S. pombe SPBC1198.02

A. thaliana ADA

B. taurus ADA

H. sapiens ADA1
- - - MVSVEFLQELPKCEHFLHLEGTLEPDLLFPLAKRNDIILF- - EGFPKSVEELNEKYKKFRDLQDFLDYYYIGTMVLI 75 MSNLPIYNFIRKLPKCEHHVHLEGCLSPDLVFRLAKKNGITLPSDDAAYTTPSTLLASYEHFGCLDDFLRYYYIAVSVLI 80 - - - - - MEWIQSLPKIELLAHLNGSIRDSTLLELARVLGEKGV - - IVFADVEHVIQKND - -RSLVEVFKLFDLIHKLTT 69 - - - MAQTPAFNKPKVELHVHLDGAIKPETILYYGRKGIALF- - ADTPEELQNIIGMDKPLSLPEFLAKFDYYMPAIAG 74 - - - -MAQTPAFDKPKVELHVHLDGSIKPETILYGRRRGIALP- - ANTAEGLLNVIGMDKPLTLPDFLAKFDYYMPAIAG 74

SEQDFFDLAWAYFKKVHKQGLVHAEVFYD - _ -

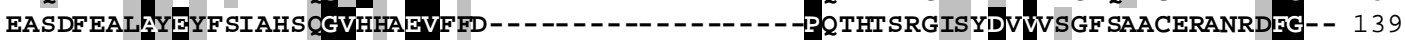
DHKTVTRITREVVEDFALENVVYLELRTTPKRSDSIGMSKRSYMEAVIOGLRSVSEVDIDFVTASDSQKLHNAGDGIGRK 149 CREAVKRIAYEFVEMKAKDGVVYVEVRYSPHLLANS - - - - - - KVEPIPWNOAEGDLTPDEMVSLVNOGLOEGERDFG - - 145 CREAIKRIAYEFVEMKAKEGVVWVEVRSPHLLANS - - - - - - -KVEPIPWNQAEGDLTPDEMVALVGGLQEGERDFG - - 145

-ITSKLIMCLLRHIEPEECLKTIEEATP- -FIKDGTISALGLDSAEKPFPPHLFV-ECYGKAASLNKDLKLIAHAGEEGP 210 - MSTNLIMCFLRH LPSEAAHETFAEALKRNDFENGIVAGVGLDSSEVDFPPELFQ-EVYKLAA - - EKGIRRTGHAGEEGD 215 KIYVRLLLSIDRRETTESAMETVKLALE- - - MRDVGVVGIDLSGNPLVGEWSTFLPALQYAKD - - NDLHIILHCGEVPN 223 - VKVRSTLCCMRHQPS - WSSEVVELCKK- - - YREQTVVAIDLAGDETIEGSSLFPGHVKAYAEAVKSGVHRTVHAGEVGS 220 -VKARSILCCMRHQPN - WSPKVVELCKK- - - YQQQTVVAIDLAGDETIPGSSLLPGHVQAYQEAVKSGIHRTVHAGEVGS 220

AOFVSDALDLLOVTRIDHEINSOYDEELLDRLSRDOTMLTICPLSNVKLOVVOSVSELPLOKFLDRDVPFSLNSDDFAYF 290 PSYIRSGLDNLSLQRIDHEIRLVEDKELMKRVAEENIMLTMCPLSNLKLRCVNSIA LPVREFLEAGVPFSINCDDPAYF 295 PKEIQAMLD-FKPHRIGHACFFKDED - -WTKLKSFRIPVEICLTSNIVTKSISSIDIHHFADL YNAKHPLILCTDDFGVF 300 ANVVKEAVDTLKTERLGHEYHTLEDATLYNRLRQENMHFEVCPWSSYLTGAWKPDTEHPVVRFKNDQVNYSLNTDDFLIF 300 AEVMKEAVDILKTERLGHGYHTLEDQALYNRLRQENMHFEICPWSSYLTGAWKPDTEHAVIRLKNDQANYSLNTDDPLIF 300

GGYILDVYTQVSKDFPHWDHETWGRIAKNAIKGSWCDDKRKNGLLSRVDEVVTKYSH- _. GGYTLENYFAIOKHF - NLTVKEWFIANAAINGSWISGKRKEELLSSVQKCVKEYTAEIOOPKTLETAVEVOA 367

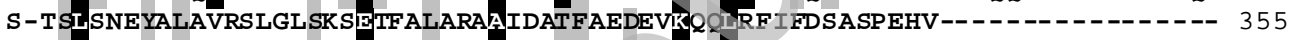
K-STLDTDYQMTKNEMGFTEEEFKRLNINAAKSSFLPEDEKKELLDLLYKAYGMPSPASAEQCL K-STLDTDYQMTKRDMGFTEEEFKRLNINAAKSSFLPEDEKRELLDLLYKAYGMPPSASAGQNL - .

B

SPBC1198. 02153 PSEAAHETFAEALKRNDFENGIVAGVGLDSSEVDFPPELFQEVYKLAAEKGIRRT GHAGE 212 PS ETFAE $R$ FE +++GV V+F E+F+ + + R

CRE1/WOL/AHK4 199 PSAIDQETFAEYTARTAFERPLLSGVAYAEKVVNFEREMFERQHNWVIKTMDR - - - - - - - 251

SPBC1198. 02213 EGDPSYIRS - - - - - -GLDNLS-LQRI DHG IRLVEDKELMKRVAEEN IML TMCPLSNLKL 264

$$
\mathrm{G}+\mathrm{PS}+\mathrm{R} \quad \mathrm{D}+\mathrm{S} \mathrm{L}+\mathrm{D}+\mathrm{DD}+\mathrm{E}+\mathrm{R}+\mathrm{E}+\mathrm{P} \mathrm{L}+
$$

CRE1/WOL/AHK4 252 -GEPSPVRDEYAPVIFSQDSVSYLESLDM-MSGEEDRENI LRARETGKAVLTSPFRLLET 309

SPBC1198.02 265 RCVNSIAELPV 275

$++P V$

CRE1/WOL/AHK4 310 HHLGWLTFPV 320

Figure 1

Licenced copy. Copying is not permitted, except with prior permission and as allowed by law. 


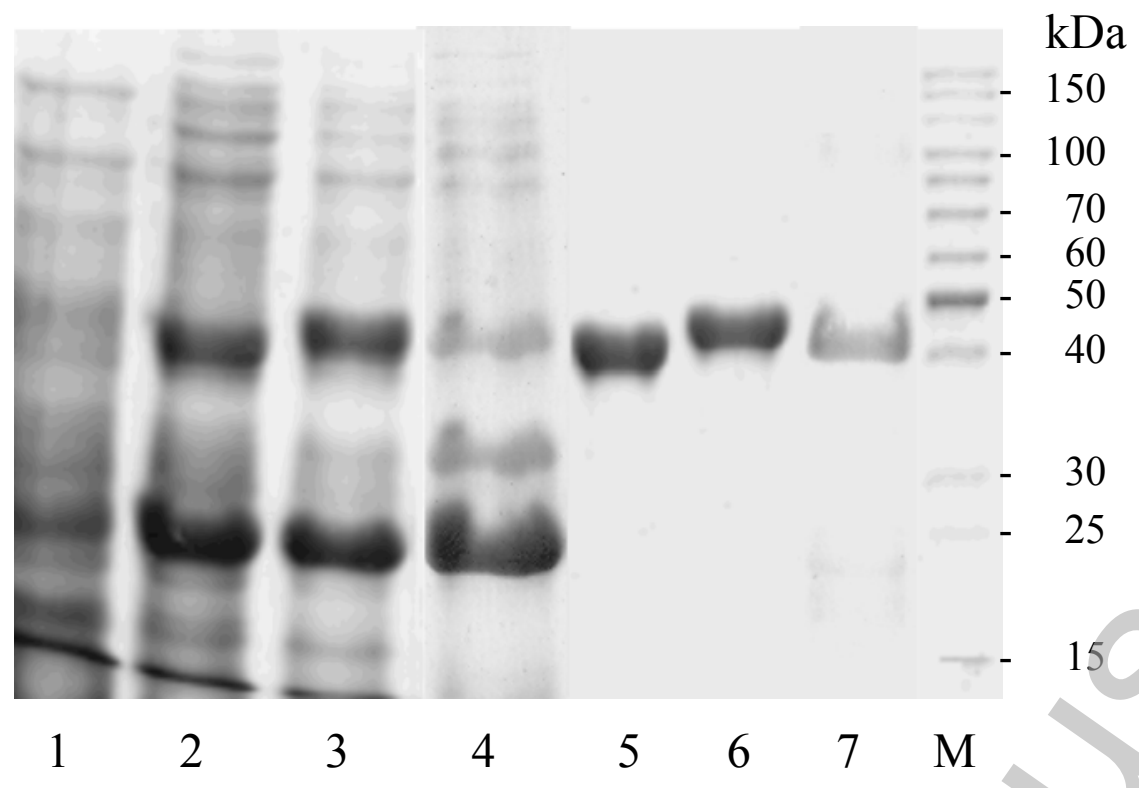

Figure 2 
Bioscience Reports Immediate Publigation. Published on 01 Aug 2008 as manuscript BSR20080081

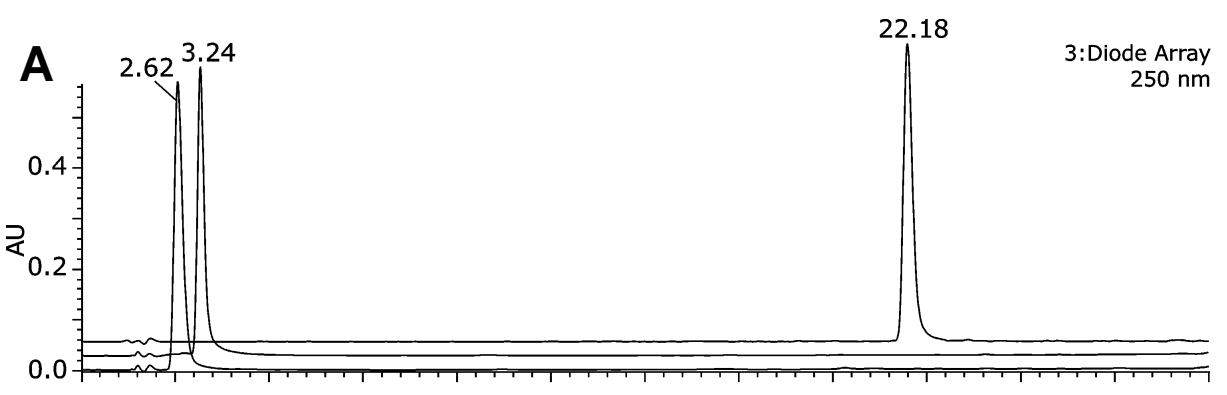

D
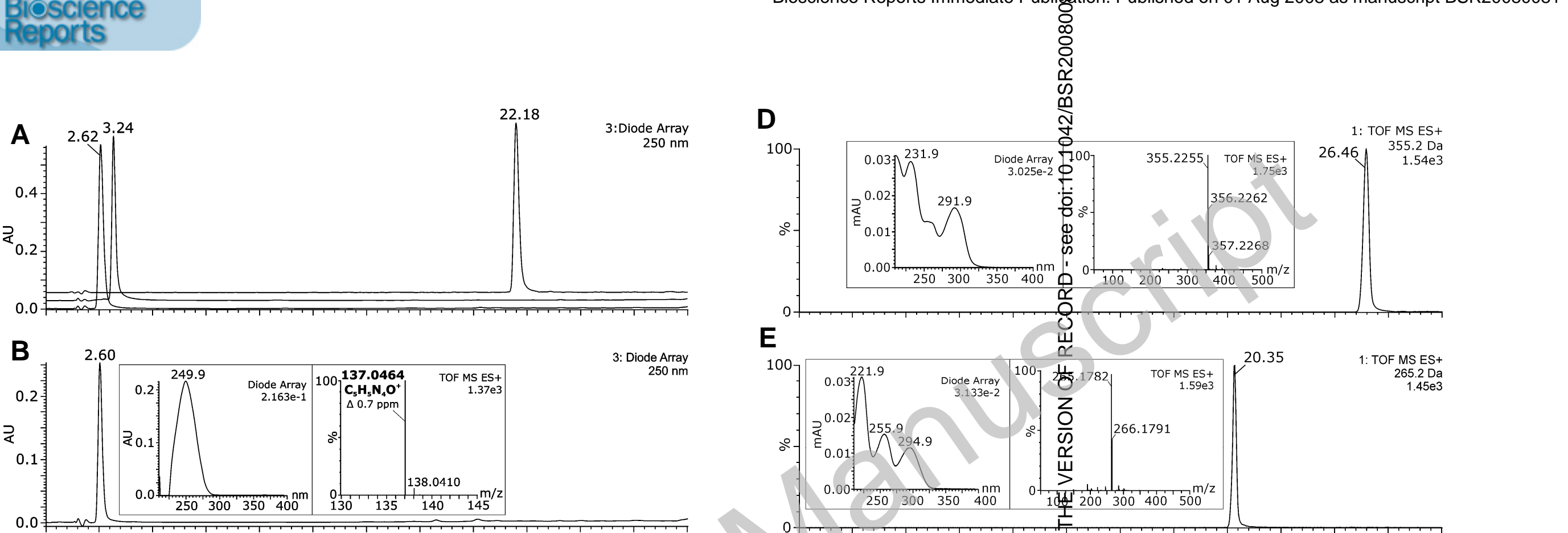

D

政

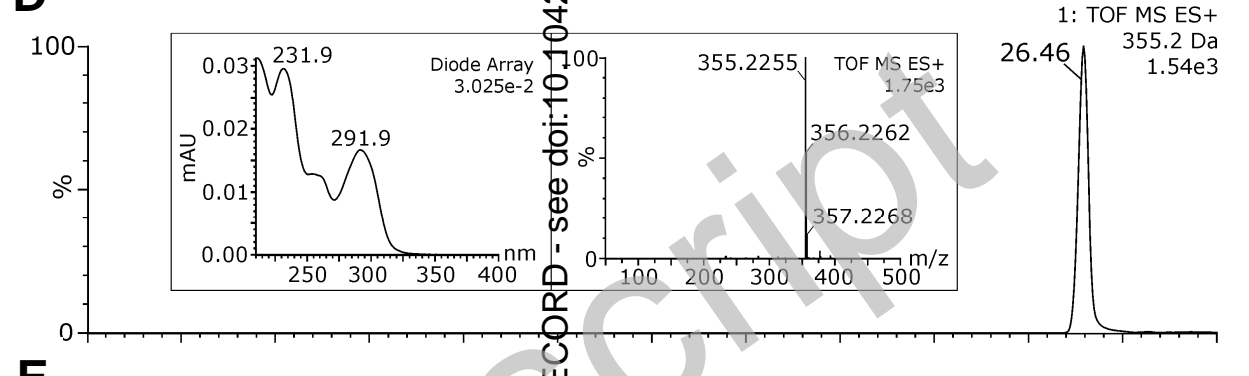

E

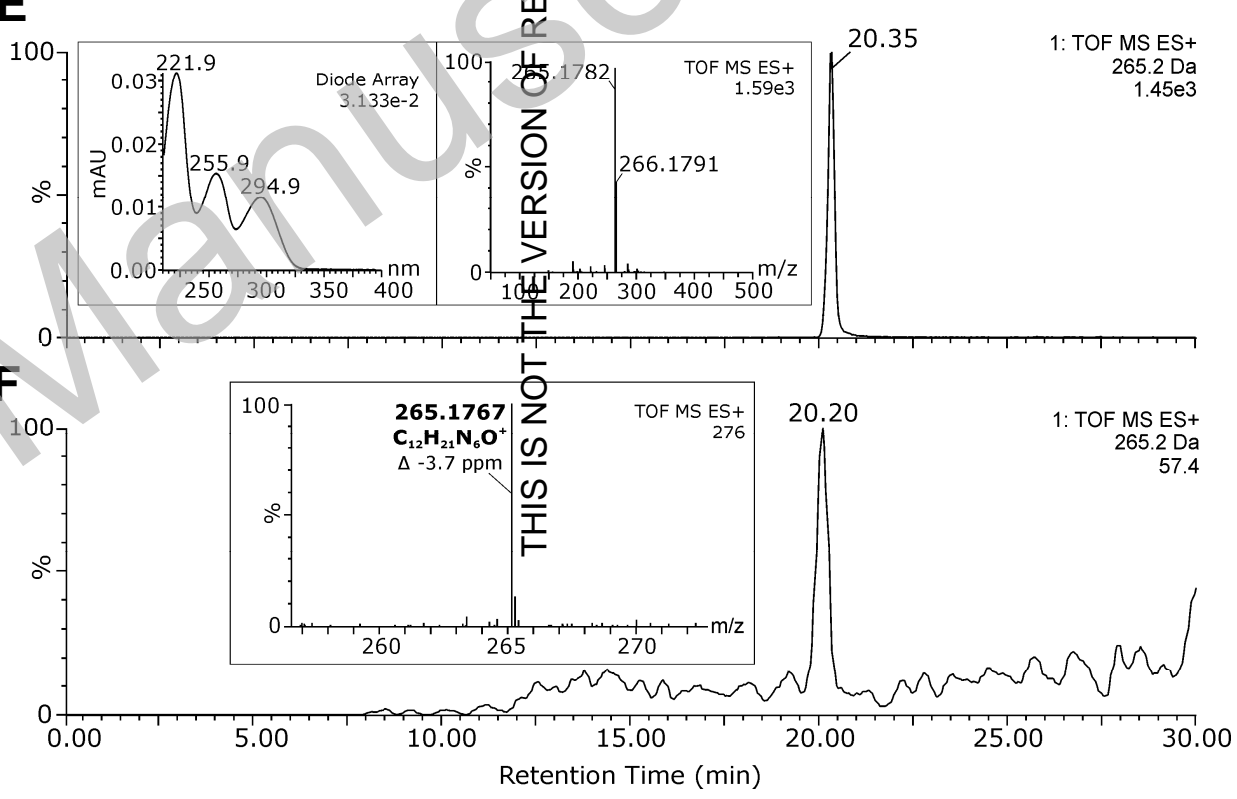

Figure 3

Licenced copy. Copying is not permitted, except with prior permission and as allowed by law.

(c) 2008 The Authors Journal compilation (@ 2008 Biochemical Society 
A<smiles>[R]n1cnc2c(N)ncnc21</smiles>

B<smiles>[R]n1cnc2c(NCc3ccco3)ncnc21</smiles>

C<smiles>CCC(CO)Nc1nc(NCc2ccccc2)c2ncn(C(C)C)c2n1</smiles>

ADE/ADA

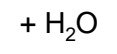<smiles>[2H]n1[cH+]cnc2c(O)ncnc21</smiles>

ADE<smiles>[18OH][18OH]</smiles><smiles></smiles><smiles>NCc1ccco1</smiles>

ADA<smiles></smiles>

Figure 4 

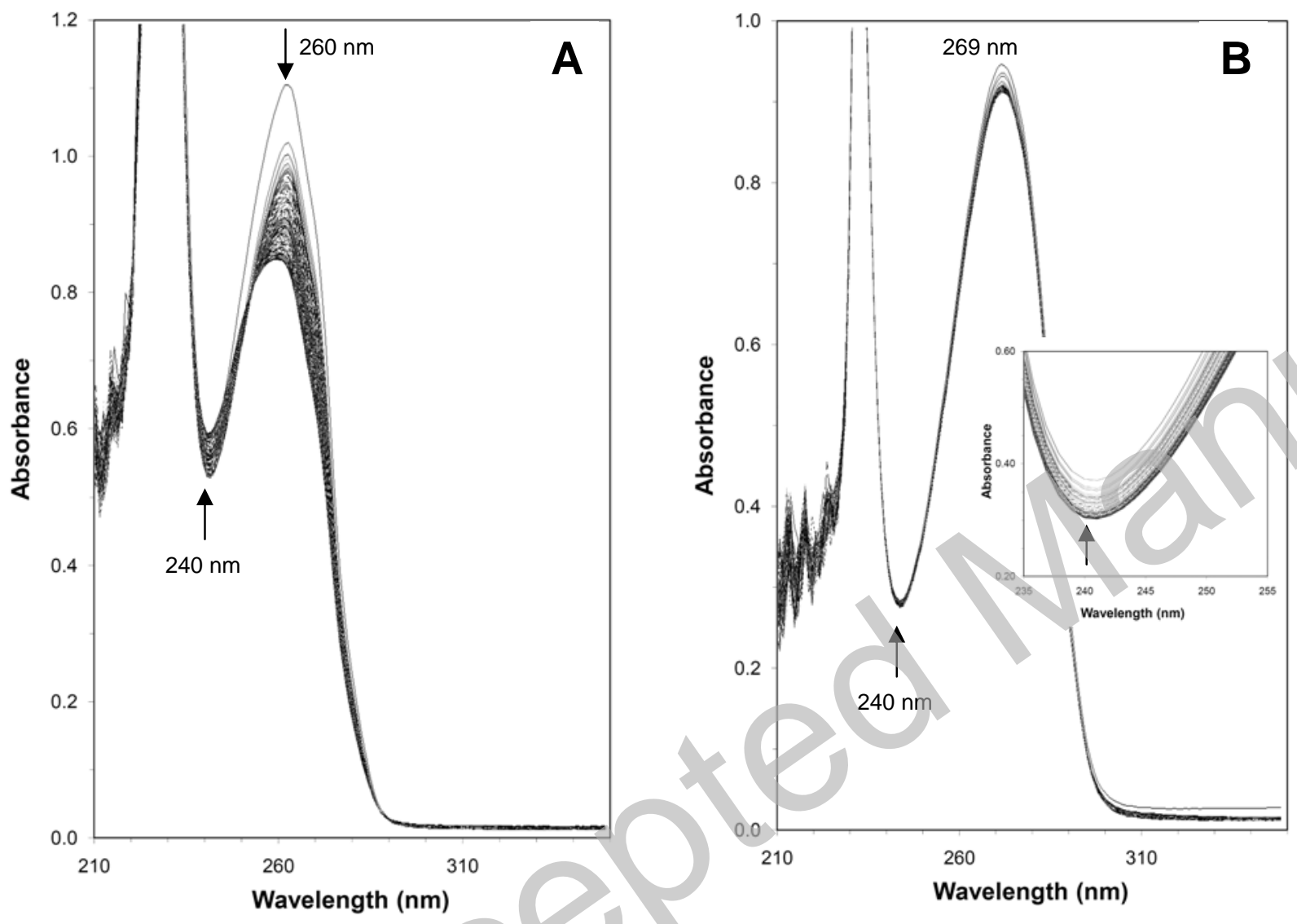

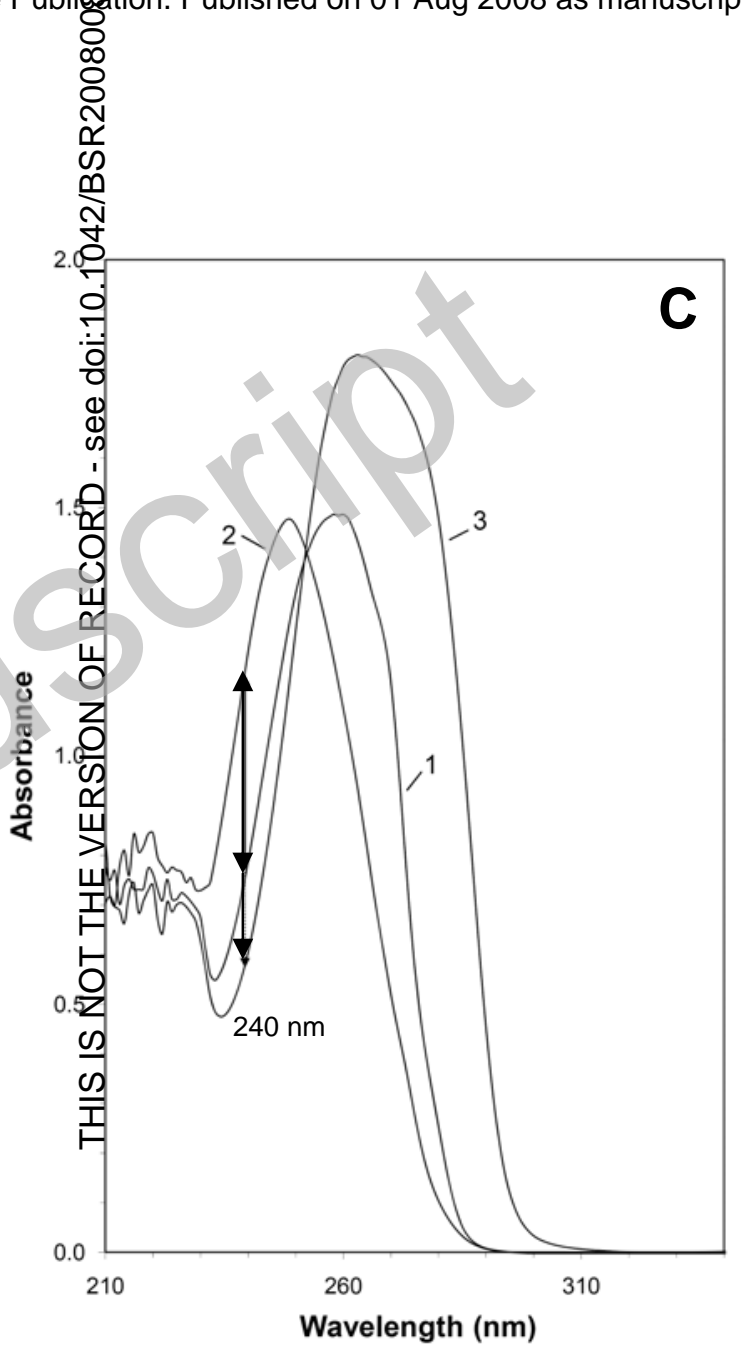

Figure 5 

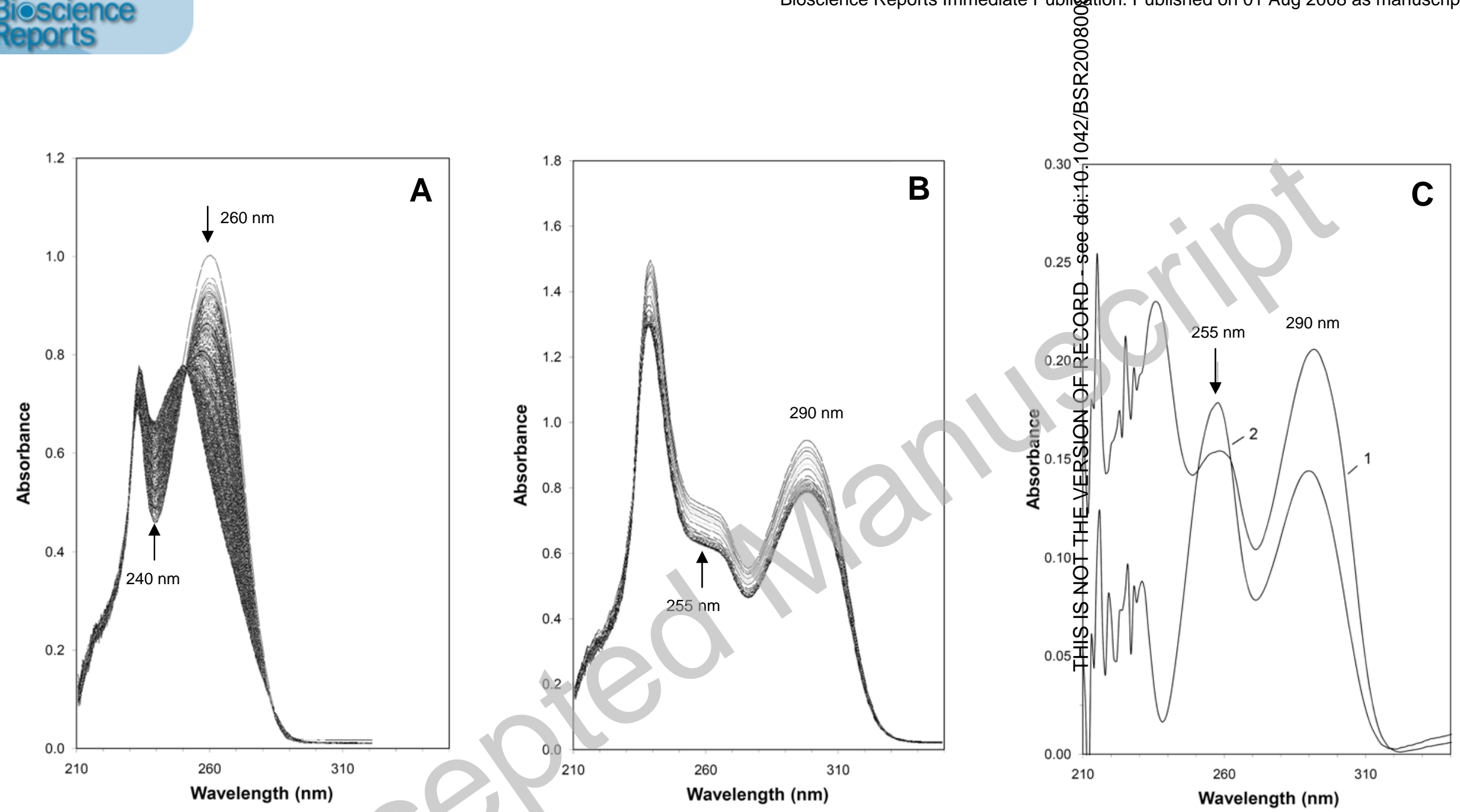

Figure 6 